\title{
Selecting suppliers for socially sustainable supply chain management: Post-exchange supplier development activities as pre-selection requirements
}

\author{
Dr Rosanna Cole (corresponding author) \\ University of Surrey, Guildford, GU2 7XH, UK \\ r.cole@surrey.ac.uk 01483683642 \\ Professor James Aitken \\ University of Surrey, Guildford, GU2 7XH, UK \\ james.aitken@surrey.ac.uk 01483300800
}

\begin{abstract}
The aim of this paper is to provide an understanding of how the supplier selection process used by buying organisations to establish socially sustainable supply chains has evolved from the traditional purchasing function. Through the application of a socially responsible purchasing (SRP) approach, organisations are attempting to address the challenges of selecting appropriate suppliers to engage with. To achieve SRP, behavioural agency attributes were found to complement traditional agency forms of governance from the start of the process. Through the use of an exploratory case study approach, three focal (purchasing) firms pursuing a strong sustainability agenda, and two supply chain intermediary organisations were investigated. The results show that supplier development activities previously positioned post-selection, are now performed at the pre-selection stage, moving them to the beginning of the process. Suppliers must now demonstrate commitment to sustainability through implementing improvements highlighted in corrective action reports at the pre-selection point before any financial transactions occur. The movement of post-selection supplier development activities to the preselection stage, to align sustainability goals and reduce risk, is a significant finding of this paper that purchasing personnel and suppliers should consider in the establishment of a socially sustainable supply chain.
\end{abstract}

Keywords sustainable supply chain management, socially responsible purchasing, supplier selection, behavioural agency theory 


\section{Introduction}

Socially sustainable supply chain management (SSSCM) is a challenging area for both the academic and practitioner communities as they strive to understand and manage the potential issues that can arise from the behaviour and activities of the supply base (Seuring and Gold 2013). Socially responsible purchasing (SRP) research, where buyers seek to source sustainably from suppliers who are adopting fair operating practices is gaining ground. Through case study research investigating SRP, this paper identifies the changes in the traditional supplier selection process that buying organisations are developing to work with potential suppliers to deliver social sustainability. As we investigate the process changes characterised by information asymmetry issues of partnering with a new supplier, we apply a principal-agency theory (PAT) lens typically used in supplier selection research to explain any changes for SRP because of the risk associated with poor sustainability practice in the supply chain (SC).

Research into the broader concept of sustainable supply chain management (SSCM) has historically focused on the economic and environmental dimensions providing narrower insights into the social aspects (Ashby, Leat and Hudson-Smith 2012; Miemczyk, Johnsen and Macquet 2012). The imbalance of research, on the premise that all three triple bottom line (TBL) dimensions are of equal standing (Carter and Easton 2011), is further exacerbated when the initial stages of forming the SC are concerned as the social aspect of the supplier selection process has historically had less attention (Zorzini et al. 2015). Recruiting appropriate suppliers is critical to buyers as supplier behaviour can have an impact on the purchasing firm in terms of reputational associations (Park-Poaps and Rees 2010; Hartmann and Moeller 2014). Social activist groups, through threats of boycotts, have become another concern for corporations forcing them to quickly and publicly address SSSCM issues (Pacheco and Dean, 2015). Increasing sources of external pressures highlights the importance of supplier selection in establishing a socially sustainable supply chain and underpins the need to understand the process that can be deployed to support its delivery.

The implementation of social sustainability relies strongly on the purchasing function and its use of SRP in selecting appropriate suppliers (Maignan, Hillebrand and McAlister 2002; Schneider and Wallenburg 2012). Engaging new vendors in the SC puts supplier selection 
decisions at the centre of SRP activity for organisations striving for SSSCM. Supplier selection is at the very beginning of the SSSCM pursuit which may or not trigger diffusion throughout the SC and benefit wider society through fair employment and the eradication of modern slavery. With such importance placed on the purchasing function, the literature does not currently offer understanding of how social sustainability pursuit changes the supplier selection process from the traditional function. In order to address this research gap and support buying organisations in their socially sustainable journey, we address the following questions, leading to the development of three propositions on the issues identified:

1. How has the traditional supplier selection process changed to support SRP?

2. Why have changes to the way suppliers are selected occurred?

3. How has the typical PAT explanation of the buyer and supplier exchange evolved in SRP?

The next section of this paper considers three strands of literature; that of traditional supplier selection processes, SRP and supplier development as a post-exchange activity. Following this, the explorative case study approach that was utilised and the results obtained are presented. The discussion explores the contribution of the research and presents the SRP supplier selection process. Finally the conclusion is presented along with the managerial implications, limitations and future research opportunities.

\section{Literature Review}

\subsection{Supplier Selection Processes}

Traditional supplier selection has played a critical role in meeting corporate objectives and minimising supply risk in a competitive environment. Suppliers are partners tasked with improving SC performance, traditionally using agency governance mechanisms of contracts and control to reduce information asymmetry, goal incongruence and mitigate against uncertainty (Fayezi, O'Loughlin and Zutshi 2012). How to select suppliers and what criteria to use has been heavily researched. Chai et al. (2013) provide a full review of the literature on supplier selection decision-making techniques. Large scale reviews of key supplier selection criteria have been conducted since the 1960s (e.g. Dickson 1966; Weber, Current and Benton 1991; Cheraghi, Dadashzadeh and Subramaniam 2004). The historically important quality, cost and delivery (Q,C,D) measures continue to dominate supplier selection decisions yet are 
supplemented by non-economic criteria, such as occupational health and safety systems (Luthra et al. 2017; Yu, Yang and Chang 2018).

A typical supplier selection process is shown in Figure 1. Using qualitative and quantitative data, buyers select a supplier based on criteria measures and sometimes, subjective judgement. Evidence of supplier traits (or order winners and qualifiers) are demonstrated through selfassessment or audit investigation before the exchange occurs.

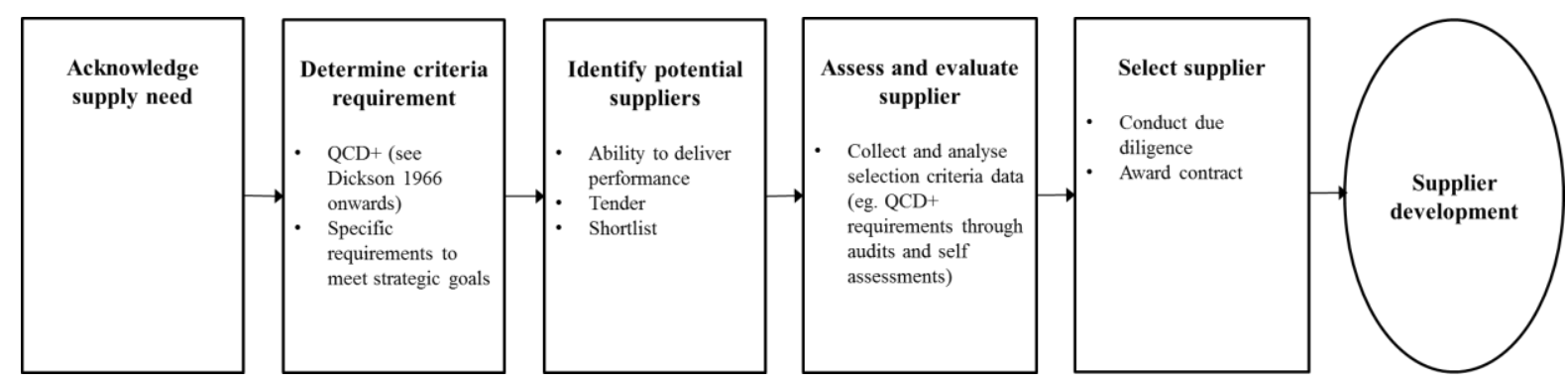

Figure 1. Supplier selection process (based on Ellram 1990; Sarkis and Talluri 2002)

Within the context of purchasing, PAT has become an established framework to investigate buyer-supplier exchanges from an economic perspective (Fayezi, O'Loughlin and Zutshi 2012) and more recently an environmental standpoint (Zsidisin and Ellram, 2003; Berrone and Gomez-Mejia, 2009; Sarkis et al. 2011). The literature largely supports the use of agency mechanisms in the pre-selection stage. PAT is based on the premise that the principal (buyer) authorises the agent (supplier) to act on the principal's behalf (Eisenhardt, 1989). The theory has historically focused on the transactional side of the exchange by encouraging the use of governance mechanisms, such as incentives and contracts for aligning the interests of principals and agents when there are competing interests and objectives in an exchange and thus reduces the risk of opportunism. PAT covers this misalignment between objectives whereby 'rational individuals will favour alternatives that enhance their own utility' (Cuevas-Rodríguez et al. 2012, 526). Alignment can also reduce reputational risk associated with suppliers' behaviour as certain events can 'occur which may have a resulting detrimental consequence on the [purchasing] firm' (Zsidisin and Ellram, 2003, 15). For example, moral hazard, in a SSCM context, refers to the risk that purchasing firms encounter from suppliers who do not demonstrate the agreed upon sustainability performance objectives. Adverse selection, on the other hand, involves the misrepresentation of a supplier's ability to meet these requirements. 
Through PAT the application of mechanisms such as certification and self-assessment provide purchasing principals the opportunity to gather information about suppliers' behaviours to minimise risk (Zsidisin and Smith 2005). The approach has been shown to provide underpinning theory to investigate current and evolving supplier-buyer activities for SSCM. For example, research into environmental SSCM practices has applied PAT to understand the use of control and incentives to encourage and govern suppliers to develop a green SC (Kogg 2003; Sanchez-Rodrigues et al. 2008). This paper engages PAT to understand how SRP is being deployed to develop buyer-supplier exchanges.

Behavioural agency theory argues that the economic model of PAT is too simplistic and needs a reconceptualization in the modern world where relational aspects of behaviour are considered (Pepper 2015). Behavioural agency theory is being developed in executive compensation realms (Pepper and Gore 2015), where traditional PAT originated from. In the same way that PAT has been adapted from a shareholder-manager to a buyer-supplier context for supply chain management, behavioural agency theory will also have some differences when applied. For example, aspects related to discounting and inequity aversion will not hold, but the incorporation of goal-setting theory to the agency model, on the basis that SSCM is linked to mutual goals, does (Pagell and Wu 2017). Buyers and suppliers may have conflicting goals of cost or delivery, but have mutual goals for sustainable development and performance. It holds that alternative theoretical perspectives 'describe circumstances under which honesty, loyalty, and trust in agents' behaviours are possible and the development of cooperative rather than contentious relationships" can be achieved (Cuevas-Rodríguez, Gomez-Mejia and Wiseman 2012, 526). It is highly useful to widen the PAT concept by using a behavioural perspective (Wilhelm et al. 2016).

The opaqueness of social sustainability measurement and selection criteria presents challenges to buying organisations in terms of how they manage their exchanges with suppliers (Wagner and Svensson 2010). Drawing from PAT, transactional factors often focus on protection from self-interest, documented processes and conflict and risk management. Relational factors are those that 'emphasise inherent and moral control, governing exchanges through consistent goals and cooperative atmospheres' (Liu, Luo and Liu 2009, 294). Overall, the buyer-supplier exchange benefits the most when both contractual and relational norms are used jointly than when used separately (Poppo and Zenger 2002; Liu, Luo and Liu 2009). However, the 
traditional supplier selection process in Figure 1 relies almost entirely on agency based transactional mechanisms with some signals of transparency and engagement through suppliers' willingness to complete self-assessment (Ellram 1990; Sarkis and Talluri 2002) reflecting the formalised and standardised approach of economically based traditional supplier selection processes. There is limited evidence of collaborative or relational behaviours being present in the historical linear approach to supplier selection at the pre-selection stage. But the function of purchasing has evolved beyond transaction-based exchange.

\subsection{Socially Responsible Purchasing (SRP)}

SRP can be defined as the 'inclusion in purchasing decisions of the social issues advocated by organisational stakeholders' (Maignan, Hillebrand and McAlister 2002, 642). Through the inclusion of social and ethical aspects into purchasing decisions which includes specific sustainability criteria for supplier selection, organisations can improve their overall corporate social responsibility reputation and record. It is achieved by extending social responsibility initiatives and accountability beyond the buyer and into the supplier network as a mode of operation to ensure good business practice. Garetti and Taisch (2012) recognise supply chain sustainability as a shift in thinking in many organisations and their SCs, from models based on old paradigms to options for building new solutions and business models towards a new sustainable world. SRP is gradually being adopted in business contexts as the advantages of sustainable sourcing are significant (Paulraj 2011). The difference between the potential benefits and actual usage may be attributed to the lack of processes or instruments for its efficient introduction (Schneider and Wallenburg 2012). The concept and its application require significant development in terms of the processes to implement and criteria to control and monitor suppliers (Wagner and Svensson 2010; Xu et al. 2019).

Due to the diversity and variety of social dimensions, it is challenging for organisations to develop criteria that encapsulate all social aspects of human rights, child labour, health and safety issues, workers' rights, wages, workforce issues related to disabled workers, racial equality, minorities, equal opportunities, corruption and product safety. Supporting an improvement in the social aspect of sustainability requires that social criteria be included in a purchasing policy which determines supplier selection (Maignan, Hillebrand and McAlister 2002, Seuring and Müller 2008; Leire and Mont 2010). Luthra et al. (2017) have attempted to 
develop a criteria framework for supplier selection incorporating economic, environmental and social dimensions at a high level. But the multitude of criteria to select and monitor suppliers is complicated by a shortage of recognised standards and measures for SR purchasers to use (Pagell and Wu 2009; Ashby, Leat and Hudson-Smith 2012, Gold, Trautrims and Trodd, 2015). Thus, organisations are attempting to work with suppliers to agree and operate a SRP framework that can underpin their drive for sustainable development while recognising the limitations of knowledge on what derives a socially sustainable supply chain (Zorzini et al. 2015). Attempts to define guidelines and a list of appropriate social criteria for suppliers has come from the amalgamation of a variety of direct and indirect sources such as global conventions and supply chain intermediaries (Leire and Mont 2010; Genovese et al. 2014; Hannibal and Kauppi 2018). These independent intermediary organisations have attempted to fill the knowledge void through developing their own frameworks and guidelines, as well as managing the supplier self-assessment process for purchasers and developing corrective action reports (CARs) for suppliers. SC intermediary organisations include organisations such as the Supplier Ethical Data Exchange (SEDEX), Aim Progress, Ethical Trade Initiative (ETI), Ecovardis, 2degrees and Sustainalytics.

The issue of forced labour is a primary social sustainability concern for organisations who are attempting to eradicate exploitative practices of modern slavery from their SCs (New, 2015). Gold, Trautrims and Trodd (2015) explain that due to this lack of effective indicators, new tools and measurement systems need to be developed and along with Marshall et al. (2015) they call for new theory development in supply chain management (SCM) as urgently needed to facilitate the understanding, avoidance and elimination of slavery in SCs. Focal companies have been blamed for deliberately not trying hard enough to detect those exploitative practices (Wolf 2014) which SRP by its very objective would mitigate. Stevenson and Cole (2018) analysed detection and remediation practices of large buyers, which are crucial to developing capability to improve SCs (Gold, Trautrims and Trodd 2015). However, New (2015) explains that legislation and policy improvements for modern slavery are in reality, unlikely to lead to much progress and a reappraisal of business models is required, in line with Garetti and Taisch $(2012,83)$ who propose new developments in process and models as the 'cornerstone of the new sustainable world'. Thus, the possibilities that a SRP process can bring to industry are ripe for further investigation. 


\subsection{Supplier development}

Following a supplier selection decision, it is common for buyers and suppliers to engage in supplier development programmes aimed at continually enhancing the suppliers' capability to better serve the buying firms' long-term needs (Hahn, Watts and Kim 1990). Once selection has taken place and the commercial exchange has begun, these programmes can be used to monitor and govern supplier behaviour to reduce risk in the ongoing relationship. Supplier development programmes typically include education and training for supplier personnel, supplier performance assessment, supplier incentives and direct financial investment by buying firms in the suppliers' capabilities (Li, Kang and Haney 2017).

In manufacturing settings, supplier development programmes have traditionally centred on cost reduction, operational efficiencies, quality management, new technology adoption and product design (Talluri et al. 2010) and more recently, sustainability behaviour (Sancha et al. 2015a). Many sectors employ supplier development programmes such as automobile assembly (Hyundai), aircraft manufacture (BAE systems), electronics production (Pulse Electronics), and other machinery and robotics (ABB). These types of programmes have proven to benefit both buyers and suppliers (Sancha et al. 2015b) leading to increased performance (Modi and Mabert 2007, Li, Kang and Haney 2017; Zhang, Pawar and Bhardwaj 2017), long term competitive advantage, and increased trust (Nagati and Rebolledo 2013). Ghijsen, Semeijn and Ernstson (2010) found that supplier development has advantages to the supplier such as their improved satisfaction and commitment. Where supplier capabilities relating to SSCM are developed, sustainability performance of the SC is enhanced (Li, Kang and Haney 2017; Zhang, Pawar and Bhardwaj 2017). In SSSCM they improve operational and social performance for the buyer and supplier, respectively (Sancha et al. 2015b). Conforming to required CSR standards can involve heavy costs in terms of time and expertise (Ayuso, Roca and Colome 2013), but supplier development programmes can provide support and resources to suppliers to ensure that their CSR capabilities are equal to or greater than a company's competitors' suppliers (Gimenez and Tachizawa 2012).

The literature indicates that, traditionally, supplier development has been a post-selection activity (Krause et al. 1998; Prahinski and Benton 2004; Talluri and Narasimhan 2004; Araz and Ozkarahan 2007; Wagner and Krause 2009; Park et al. 2010; Wagner 2011). For example, 
it has been suggested that for supplier development to work, the partnership needs to already be successful and established (Talluri and Narasimhan 2004; Araz and Ozkarahan 2007). This is because often buyers need to invest in supplier development programmes. More evidence pointing to supplier development as a post-exchange activity is provided by Foerstl et al. (2010) who state that a structured evaluation and subsequent supplier selection allow a company to effectively manage a sustainable portfolio of suppliers. However, early supplier involvement in some contexts exists. For example, it started in new product development for Japanese automobiles and exists for firms pursuing open innovation (Luzzini et al. 2015). Competitive forces encourage new and established suppliers to speed up their innovation processes and to improve integration capabilities to reach strategic goals. The conditions for the cooperation and development of supplier skills need to be considered just as in post-exchange supplier development.

The historical approach to supplier selection (Figure 1) provides a blueprint in which to begin to understand the changes that may have to occur to develop a SRP based SC. Through exploring case studies of companies that are actively pursuing SSSCM, the paper will examine SRP practices. Understanding how the selection challenges are being addressed through SRP offers the potential of gaining insights into the underlying processes that purchasing professionals are utilising by employing an SRP strategy.

Our research questions are derived from the literature where we observe the following practices. Firstly, PAT is a popular and suitable theoretical perspective for traditional operations management (Walker et al. 2015) and also for purchasing and SCM research (Johnsen, Miemczyk and Howard, 2016) due to levels of risk, information asymmetry and the nature of the buyer-supplier exchange. Secondly, supplier development programmes are useful to determine and develop supplier sustainability capabilities (Zhang et al. 2013) but that they occur post-exchange. 


\section{Methodology}

\subsection{Research Design}

Our research was conducted through exploratory case studies addressing the aims of the investigation (Eisenhardt and Graebner 2007) and with the objective to report on solutions to real operations management problems (McCutcheon and Meredith, 1993). For example, Despeisse et al. (2012) observe the need for researchers to document, analyse and publish more cases on the practice and benefits of sustainable operations. The purpose of the case study approach is to investigate real changes in the supplier selection process for firms pursuing social sustainability improvements in their supply chains demonstrated by their strategic objectives to select suitable suppliers. The research design employs multiple cases which permits 'replication' logic (Yin 1984) in which the cases are treated as a series of independent studies that confirm or disconfirm emerging conceptual insights, using document and interview analysis within cases and across cases.

The research design consisted of three main focal (purchasing) firms who are exemplary in SRP. In order to investigate changes to the traditional purchasing process and behaviours required from suppliers in SRP, organisations practicing this were needed for the study. The criteria for case selection and rationale for choosing those organisations are shown in Table 1. The three in-depth case studies have pseudonyms of BevAware, JustProduce and ApparelTrade. 


\begin{tabular}{l|l|l}
\hline Criteria for main case selection & Defined by & Rationale \\
\hline $\begin{array}{l}\text { Must be an exemplar firm } \\
\text { practicing SRP }\end{array}$ & $\begin{array}{l}\text { Highest ranking membership on } \\
\text { SEDEX and public declarations of } \\
\text { SRP }\end{array}$ & $\begin{array}{l}\text { To investigate what they do differently to } \\
\text { traditional purchasing processes shown in } \\
\text { literature }\end{array}$ \\
\hline $\begin{array}{l}\text { Must have specific global } \\
\text { sustainable sourcing policies }\end{array}$ & $\begin{array}{l}\text { Public sourcing policy available on } \\
\text { website specific to the company }\end{array}$ & $\begin{array}{l}\text { Evidence of pursuit of social sustainability in } \\
\text { SC which provides basis for further } \\
\text { questioning of process }\end{array}$ \\
\hline $\begin{array}{l}\text { Must work with SC } \\
\text { intermediaries to improve supply } \\
\text { chain sustainability performance }\end{array}$ & $\begin{array}{l}\text { Confirmed membership status of the } \\
\text { ETI and SEDEX }\end{array}$ & $\begin{array}{l}\text { Example of exemplar activity through } \\
\text { memberships and evidence that purchasers } \\
\text { work with intermediaries who then validate } \\
\text { their claims }\end{array}$ \\
\hline $\begin{array}{l}\text { Must operate in either the global } \\
\text { food, beverage or fast fashion } \\
\text { sector }\end{array}$ & $\begin{array}{l}\text { Industry Classification Benchmark } \\
\text { (consumer goods>food and } \\
\text { beverage OR personal and } \\
\text { household) }\end{array}$ & $\begin{array}{l}\text { Food and apparel organisations are } \\
\text { commonly objects of research on sustainable } \\
\text { supply chains (Wilhelm et al. 2016) because } \\
\text { customer-facing brand image is important to } \\
\text { reputational risk }\end{array}$ \\
\hline $\begin{array}{l}\text { Must have a UK Headquarters } \\
\text { with }+3500 \text { employees and be } \\
\text { listed on the FTSE with }+£ 700 m \\
\text { annual revenue }\end{array}$ & $\begin{array}{l}\text { Disclosure on website and FTSE } \\
\text { lists }\end{array}$ & $\begin{array}{l}\text { Large vanguard firms viewed as leaders in } \\
\text { SRP in industry provide context for studying } \\
\text { phenomenon }\end{array}$ \\
\hline $\begin{array}{l}\text { Must have a global supplier } \\
\text { network with supplier spend of } \\
+£ 500 m\end{array}$ & $\begin{array}{l}\text { Disclosure on website or company } \\
\text { global sourcing map }\end{array}$ & $\begin{array}{l}\text { Supplier selection decisions need to be a key } \\
\text { role of purchasing function due to number } \\
\text { and complexity of suppliers }\end{array}$ \\
\hline
\end{tabular}

Table 1. Main case selection criteria

\subsection{Data Collection}

Data was collected through a multiple-method approach including internal document review of 46 documents and 31 interviews to challenge and clarify information (Voss, Tsikriktsis and Frohlich 2002). Company documents were analysed for all cases using the coding techniques described in the data analysis section. These documents included organisational strategic objectives, sustainability strategies, responsible procurement strategies and codes of business conduct. The semi-structured interviews were conducted over a period of 15 months across the cases. Participants included buyers, ethical trade and responsible sourcing analysts and managers, and corporate sustainability managers within the firms. The breadth of respondents provided access to individuals who make the initial supplier selection decisions, manage the supplier base, input into the sustainability strategy at a corporate level and liaise with SC intermediaries regarding sustainability criteria measures (see Table 2). Therefore exposure to a range of roles involved in both creating and managing the sustainability policies and behaviour of the organisations involved was achieved. Judgement and snowball sampling was used to infiltrate the wider network within the organisations as introductions were made to more people and interviews were conducted specifically with individuals who had insight into 
the process. An interview guide was used to guide the semi-structured interviews (see Appendix 1). The questions are specifically designed to answer the research questions.

Table 2 shows the case company, breakdown of the document analysis in terms of number of documents and pages considered, examples of types of documents reviewed, job role of each person interviewed for each case and how their data was collected. It confirms that judgement was used in the sampling to ensure that the individuals that were interviewed were the people responsible for formulating strategic objectives, making the supplier selection decisions and identifying criteria related to social sustainability behaviour. The documents broadly cover policy documents, reports, guidance pages, publicity messages, and self-assessment tools. All interviews were audio recorded, transcribed and coded. All face to face interviews were conducted on company site.

\subsection{Validation techniques}

Once data was collected and analysed from the main cases, the results were tested in two ways. Firstly, two additional case organisations who assist in the process of supplier selection were researched. They are supply chain intermediary organisations. These are referred to as validation cases as they do not complete purchasing activities themselves, but are used to ratify the findings and saturation of the three main focal purchasing firms. The two validation cases are global supply chain intermediaries who assess organisations and their supply chains using online platforms to achieve improvements of ethical standards of practice. They have pseudonyms of InfOrg and SociOrg and their key function is to facilitate supplier selection. The intermediaries go some way towards representing the supplier voice as they hold a middle role between the two transacting parties. However it is the perspective of the buyer that is of primary interest in the research to investigate the buyer decision and selected supplier outcome. For the validation cases, business development managers (or equivalent) were interviewed to gain an insight into their experience of buyers. Secondly, once theoretical saturation for the cases occurred, additional research conversations with BevAware were conducted to ratify the final constructs, demonstrating an abductive methodology in order to achieve repeat and reflective confirmation of the findings from the business. The data collection was abductive as the three main cases were investigated, then supported by validation cases as saturation was reached - whereby diminishing returns from incremental cases or interviews deem the 
continuation of those exact research objectives redundant (Voss, Tsikriktsis and Frohlich, 2002) and then reconfirmed with BevAware (as the first case) in a return visit. Validation is valuable to ensure that the buyer's change in process description and explanation is reinforced by the intermediaries supporting the service and enhances our critical realist design. The validation participants were interviewed towards the end of the main study data collection process using the final coding scheme, which they confirmed, as did the participants in the revisit to BevAware with the final findings. These were the same participants who were involved in the initial exploratory investigations. 


\begin{tabular}{|c|c|c|c|c|c|c|}
\hline Case & Description & $\begin{array}{c}\text { Documents coded } \\
\# \text { (pages) }\end{array}$ & Description of documents coded & Interviewees & Job description & Type of interview \\
\hline BevAware & $\begin{array}{l}\text { Beverage } \\
\text { manufacturer }\end{array}$ & $10(199)$ & $\begin{array}{l}\text { Partnering with Suppliers statement } \\
\text { Sustainability \& Responsibility Report } \\
\text { Shaping Our Industries Future - A Call to Action [1] [2] } \\
\text { Case studies Occupational Health and Safety Global Policy } \\
\text { California Transparency in Supply Chains Act } \\
\text { Code of Business Conduct } \\
\text { Human Rights and Anti-discrimination Global Policy } \\
\text { Marketing code }\end{array}$ & $\begin{array}{l}1 \\
2 \\
3 \\
4 \\
5 \\
6 \\
7 \\
8\end{array}$ & $\begin{array}{l}\text { Global Sustainability Manager, Procurement } \\
\text { Sustainability, Risk and Compliance Manager, } \\
\text { Procurement } \\
\text { Sustainability and Responsibility Performance } \\
\text { Manager } \\
\text { Supplier Performance Manager } \\
\text { Supplier Performance Manager } \\
\text { Global Sustainability Assistant, Procurement } \\
\text { Global Procurement Programme Manager } \\
\text { Global Procurement Category Manager }\end{array}$ & $\begin{array}{l}\text { Face to face } \\
\text { Face to face } \\
\text { Face to face } \\
\text { Face to face } \\
\text { Face to face } \\
\text { Face to face } \\
\text { Face to face } \\
\text { Face to face }\end{array}$ \\
\hline JustProduce & $\begin{array}{l}\text { Food } \\
\text { manufacturer }\end{array}$ & $16(139)$ & $\begin{array}{l}\text { CEOs Introduction } \\
\text { News and press releases [1] [2] [3] } \\
\text { Sustainability Summary Report } \\
\text { Our Approach to an Ethical Supply Chain } \\
\text { KPIs } \\
\text { Responsible Marketing } \\
\text { Health and Safety } \\
\text { Ethical Trading } \\
\text { Health Safety \& Environmental policy statement } \\
\text { Charitable Giving Policy } \\
\text { A code of conduct for employees } \\
\text { Community Involvement Policy } \\
\text { Standard terms and conditions for the purchase of goods and } \\
\text { services }\end{array}$ & $\begin{array}{c}9 \\
10 \\
11 \\
12 \\
13 \\
14 \\
15 \\
16\end{array}$ & $\begin{array}{l}\text { Group Head of Sustainability } \\
\text { Sustainability Analyst, Procurement } \\
\text { Sustainability Analyst, Procurement } \\
\text { Purchasing Manager } \\
\text { Procurement Buyer } \\
\text { Procurement Buyer } \\
\text { Category Group Project Manager } \\
\text { Category Group Project Manager }\end{array}$ & $\begin{array}{l}\text { Face to face } \\
\text { Face to face } \\
\text { Face to face } \\
\text { Face to face } \\
\text { Telephone } \\
\text { Face to face } \\
\text { Telephone } \\
\text { Face to face }\end{array}$ \\
\hline ApparelTrade & Fashion retailer & $3(140)$ & $\begin{array}{l}\text { Annual Report } \\
\text { Operating Responsibly report } \\
\text { Supplier Policy }\end{array}$ & $\begin{array}{l}17 \\
18 \\
19 \\
20 \\
21 \\
22\end{array}$ & $\begin{array}{l}\text { Ethical Trading Manager } \\
\text { Corporate Sustainability Manager } \\
\text { Ethical Supply Chain Manager } \\
\text { Assistant Buyer } \\
\text { Assistant Buyer } \\
\text { Fashion Product Analyst } \\
\end{array}$ & $\begin{array}{l}\text { Face to face } \\
\text { Video conference } \\
\text { Face to face } \\
\text { Face to face } \\
\text { Face to face } \\
\text { Video conference }\end{array}$ \\
\hline InfOrg & SC intermediary & $13(687)$ & $\begin{array}{l}\text { Multi-tier transparency statement } \\
\text { Follow up to multi-tier transparency statement } \\
\text { Supplier Workbook } \\
\text { Members Ethical Trade Audit [1] [2] } \\
\text { Annual Review } \\
\text { Guidance to completing a self assessment } \\
\text { Overview of a corrective action report } \\
\text { Guidance to completing a corrective action report [1] [2] [3] } \\
\text { Presentation [1] [2] }\end{array}$ & $\begin{array}{l}23 \\
24 \\
25 \\
26 \\
27\end{array}$ & $\begin{array}{l}\text { Head of Stakeholder Relations } \\
\text { Stakeholder Manager } \\
\text { Stakeholder Manager } \\
\text { Supplier Engagement Manager } \\
\text { Supplier Engagement Manager }\end{array}$ & $\begin{array}{l}\text { Video conference } \\
\text { Face to face } \\
\text { Face to face } \\
\text { Video conference } \\
\text { Face to face }\end{array}$ \\
\hline \multirow[t]{2}{*}{ SociOrg } & SC intermediary & $5(83)$ & $\begin{array}{l}\text { Achieving supply chain transparency - from compliance to } \\
\text { engagement guidelines } \\
\text { Marketing Brochure } \\
\text { Ethical Fashion Forum Guidance } \\
\text { Presentation } \\
\text { Impact Report }\end{array}$ & $\begin{array}{l}28 \\
29 \\
30 \\
31\end{array}$ & $\begin{array}{l}\text { Business Development Manager } \\
\text { Business Relationship Officer } \\
\text { Business Relationship Officer } \\
\text { Project Manager }\end{array}$ & $\begin{array}{l}\text { Face to face } \\
\text { Face to face } \\
\text { Face to face } \\
\text { Face to face }\end{array}$ \\
\hline & & $47(1248)$ & & 31 & & \\
\hline
\end{tabular}

Table 2. Details of data collection per case 


\subsection{Data analysis}

The unit of analysis is the supplier selection decision - that decision may result in a supplier being selected or not. The data analysis included several steps as first, each individual case was analysed before comparing across cases to construct the framework for SRP. Documents and interviews from each case were open-coded (although a coding sheet was used after the first case). These codes emerged and developed from the narrative. A coding sheet was developed defining each category so that a second coder could be used to calculate the inter-rater reliability of the coding. We continued to collect data until no new codes were generated (Glaser and Strauss 1967; Eisenhardt 1989). In BevAware, the first case study, 18 main constructs emerged (see Figure 2). Text sections could be coded to more than one code, allowing the analysis of links to be conducted. The data that was collected was coded by two researchers 'operating in isolation from each other select the same code for the same unit of text' (Krippendorff 2004, 217). The codes developed were subjected to coding analysis interpreted using NVivo and tested through inter-rater reliability using the Kappa coefficient (to exclude the chance of agreement). An example of inter-rater reliability statistics are shown in Appendix 2. All the inter-rater reliability statistics for the constructs were higher for the documents than interviews, showing that it was clearer to code the organisational scripted evidence than the experiences of the participants. Nonetheless, the inter-rater reliability achieved is substantial throughout after the iterations of coding. Constructs demonstrated a satisfactory and substantial mean agreement with a value over 0.70 . The overall mean interrater reliability was 0.783 . With this procedure we demonstrated a systematic design to the data collection, maintained a structured procedure and documentation of the data analysis, and included multi-person involvement and quality checks (Srnka and Koeszegi 2007), thus guarding against a lack of rigour or transparency found in some operations management case based research (Voss, Tsikriktsis and Frohlich 2002; da Mota Pedrosa, Näslund and Jasmand 2012).

In JustProduce, case study two, these 18 constructs were restructured to form 11 main categories, with previous categories being absorbed by more significant constructs, depicted in grey in Figure 2. In ApparelTrade, these 11 categories were rearranged into eight areas. Theoretical saturation was reached when the validation cases confirmed that there were eight first order constructs explained in the findings. 
Once the individual cases were analysed, cross case analysis was used to identify the similarities between the organisations that drove their SRP behaviour. Many similarities between the cases were expected as the firms were chosen due to their SRP initiatives. Differences between the cases existed but were not significant enough to suggest that the SRP process and characteristics discovered altered as a result of those. What emerged from our data were insights that linked successful SRP with a set of traditional agency and behavioural agency mechanisms in supplier selection that led to a change in the SRP process from traditional sourcing. We defined successful SRP as our informants did, in terms of positive outcome supplier selection decisions based on sustainability behaviours and subsequent successful commercial relationships.

Table 3 shows the eight final constructs, their definitions which were derived from the data and examples of how they are evidenced within cases through interview data. It shows within case and cross case evidence to facilitate comparisons to develop the emerging constructs and theoretical logic. Coding of InfOrg and SociOrg documents and interviews were used to ratify both themes derived and the process model that was developed.

By presenting our methodology as per Barratt, Choi and Li's (2011) checklist to demonstrate transparency ensuring the quality and usefulness of analysing case studies in operations management research, we have firstly justified the use of cases (to investigate the SRP process and decision), explained the sampling in detail (purpose case selection on the basis of demonstrating SRP using judgement and snowball sampling), clearly stated the unit of analysis as the supplier selection decision in SRP, shown the number of cases and triangulation of data between documents and interviews (Table 3) and explained the data analysis procedure in a logical way using statistical agreement to support coding protocols and enhance validity. 


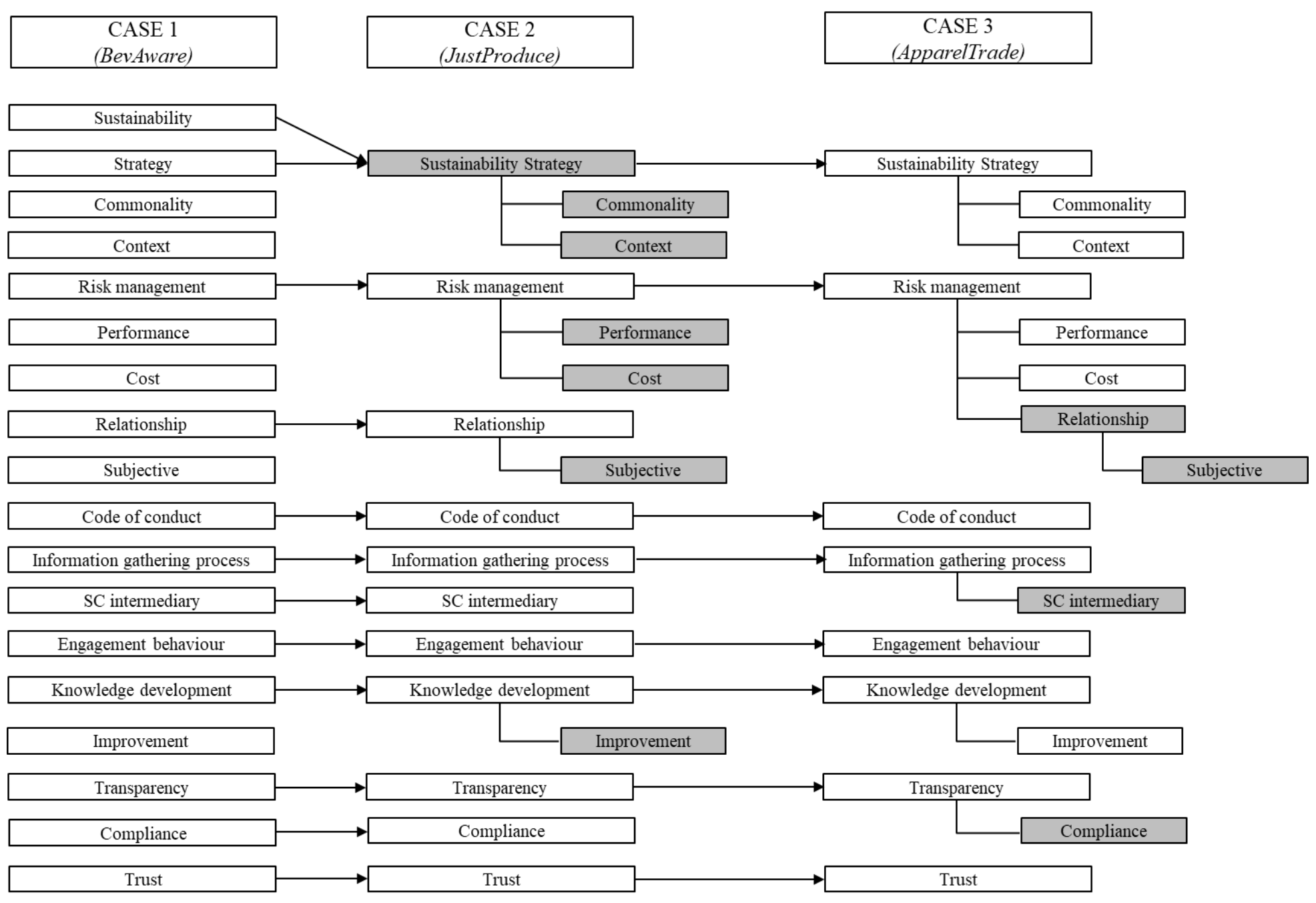

Figure 2. Coding development across organisational cases 


\begin{tabular}{|c|c|c|c|c|c|c|c|c|c|c|c|c|c|c|c|}
\hline & \multirow{4}{*}{ 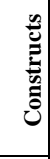 } & \multirow{4}{*}{$\begin{array}{l}\text { Definition derived } \\
\text { from the data }\end{array}$} & \multicolumn{9}{|c|}{ WITHIN CASE ANALYSIS } & \multicolumn{3}{|c|}{ CROSS CASE ANALYSIS } & \multirow{4}{*}{ Summary } \\
\hline & & & & & CASE 1 & & & CASE 2 & & & CASE 3 & \multirow{3}{*}{ Case similarities } & \multirow{3}{*}{ Case variations } & \multirow{3}{*}{$\begin{array}{l}\text { Validation case } \\
\text { support }\end{array}$} & \\
\hline & & & & & BevAware & & & JustProduce & & & ApparelTrade & & & & \\
\hline & & & $\dot{\vec{\Xi}}$ & 官 & Example of evidence & $\dot{\Xi}$ & $\stackrel{\dot{\leftrightarrow}}{\circ}$ & $\begin{array}{c}\text { Example of } \\
\text { evidence }\end{array}$ & $\dot{\vec{s}}$ & $\dot{\leftrightarrow}$ & $\begin{array}{c}\text { Example of } \\
\text { evidence }\end{array}$ & & & & \\
\hline 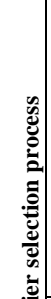 & 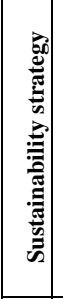 & $\begin{array}{l}\text { A plan of action } \\
\text { designed to achieve a } \\
\text { long-term or overall } \\
\text { aim in relation to } \\
\text { meeting the needs of } \\
\text { the present and } \\
\text { future generational } \\
\text { economic, } \\
\text { environmental and } \\
\text { social needs. }\end{array}$ & $\mathbf{x}$ & $\mathbf{x}$ & $\begin{array}{l}\text { "Our corporate } \\
\text { objectives and } \\
\text { sustainability } \\
\text { endeavours go hand in } \\
\text { hand. We expect our } \\
\text { business partners to } \\
\text { have similar ones" } \\
\text { Global Sustainability } \\
\text { Manager. }\end{array}$ & $\mathbf{x}$ & $\mathbf{x}$ & $\begin{array}{l}\text { "We are driven by } \\
\text { our sustainability } \\
\text { strategies and a } \\
\text { drive for } \\
\text { improvement } \\
\text { globally" Group } \\
\text { Head of } \\
\text { Sustainability. }\end{array}$ & $\mathbf{x}$ & $\mathbf{x}$ & $\begin{array}{l}\text { "Our sustainability } \\
\text { strategy is our } \\
\text { corporate strategy. It } \\
\text { drives what we do } \\
\text { and is there for } \\
\text { everyone to see" } \\
\text { Corporate } \\
\text { Sustanability } \\
\text { Manager. }\end{array}$ & $\begin{array}{l}\text { Sustainability strategy drives SRP } \\
\text { behaviour in all firms by publicly } \\
\text { providing details on corporate } \\
\text { objectives and explicit messages } \\
\text { that business partners should have } \\
\text { similar goals. }\end{array}$ & $\begin{array}{l}\text { Sustainability objectives are } \\
\text { communicated through } \\
\text { different channels e.g.. } \\
\text { BevAware and JustProduce } \\
\text { have separate specific strategy } \\
\text { documents and ApparelTrade } \\
\text { incorporate them within their } \\
\text { reporting. Some objectives are } \\
\text { industry-context specific. }\end{array}$ & $\begin{array}{l}\text { The intermediaries } \\
\text { often consult on } \\
\text { sustainability strategies } \\
\text { of large buyers to guide } \\
\text { them accordingly. }\end{array}$ & $\begin{array}{l}\text { Buyers are driven in } \\
\text { their supplier } \\
\text { selection decisions } \\
\text { by their explicit } \\
\text { sustainability } \\
\text { strategies and they } \\
\text { are looking to work } \\
\text { with suppliers who } \\
\text { have aligned goals. }\end{array}$ \\
\hline 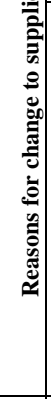 & 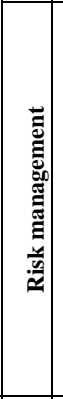 & $\begin{array}{l}\text { The actions to } \\
\text { govern a situation } \\
\text { involving exposure } \\
\text { to danger, harm or } \\
\text { loss. }\end{array}$ & $\mathbf{x}$ & $\mathbf{x}$ & $\begin{array}{l}\text { "We are a company of } \\
\text { brands and we live and } \\
\text { die by our brands. It's } \\
\text { all around brand } \\
\text { reputation. Suppliers } \\
\text { need to get that too". } \\
\text { Sustainability, Risk and } \\
\text { Compliance Manager. }\end{array}$ & $\mathbf{x}$ & $\mathbf{x}$ & $\begin{array}{l}\text { "We cannot afford } \\
\text { not to consider } \\
\text { risk in } \\
\text { sustainability". } \\
\text { Sustainability } \\
\text { Analyst. }\end{array}$ & $\mathbf{x}$ & $\mathbf{x}$ & $\begin{array}{l}\text { "Corporate } \\
\text { sustainability has } \\
\text { changed } \\
\text { significantly in } \\
\text { fifteen years, from a } \\
\text { peripheral concern } \\
\text { for large companies } \\
\text { to a key risk. There } \\
\text { is opportunity across } \\
\text { industries providing } \\
\text { they have access to } \\
\text { the information they } \\
\text { require" Ethical } \\
\text { Trading Manager. }\end{array}$ & $\begin{array}{l}\text { Risk to reputation and } \\
\text { commercial success is the main } \\
\text { reason firms pursue sustainability } \\
\text { strategies. }\end{array}$ & $\begin{array}{l}\text { BevAware, as the biggest } \\
\text { company, were most } \\
\text { concerned about brand risk. }\end{array}$ & $\begin{array}{l}\text { The experience of the } \\
\text { intermediaries is that } \\
\text { risk is the key driver } \\
\text { for buyers to use their } \\
\text { services. However, they } \\
\text { also believe that a lack } \\
\text { of specific knowledge } \\
\text { in social sustainability } \\
\text { is another important } \\
\text { reason why they are } \\
\text { utilised in the process. }\end{array}$ & $\begin{array}{l}\text { Buyers are driven by } \\
\text { the risk associated } \\
\text { with poor } \\
\text { sustainability } \\
\text { practice in their } \\
\text { supply chains when } \\
\text { selecting suppliers. }\end{array}$ \\
\hline 想 & 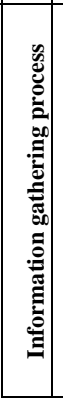 & $\begin{array}{l}\text { A series of actions or } \\
\text { steps taken in order } \\
\text { to achieve access to } \\
\text { particular data } \\
\text { required. }\end{array}$ & $\mathbf{x}$ & $\mathbf{x}$ & $\begin{array}{l}\text { "We use an } \\
\text { intermediary to collect } \\
\text { the data we need on } \\
\text { our suppliers to ensure } \\
\text { they are compliant } \\
\text { enough. Although we } \\
\text { do pre-screen before } \\
\text { this against our own } \\
\text { requirements including } \\
\text { financials and other } \\
\text { risk factors" Global } \\
\text { Sustainability } \\
\text { Assistant. }\end{array}$ & $\mathbf{x}$ & $\mathbf{x}$ & $\begin{array}{l}\text { "Information } \\
\text { gathering is less of } \\
\text { a problem than } \\
\text { accuracy of that } \\
\text { information" } \\
\text { Purchasing } \\
\text { Manager. }\end{array}$ & $\mathbf{X}$ & $\mathbf{X}$ & $\begin{array}{l}\text { "We rely on [our } \\
\text { intermediary's] } \\
\text { ability to collect } \\
\text { sustainability } \\
\text { information on our } \\
\text { suppliers prior to } \\
\text { selection" Ethical } \\
\text { Trading Manager. }\end{array}$ & $\begin{array}{l}\text { All cases rely on the intermediary } \\
\text { to facilitate information gathering } \\
\text { to know what is important and to } \\
\text { influence suppliers to comply. }\end{array}$ & $\begin{array}{l}\text { BevAware supplement the } \\
\text { intermediary's information } \\
\text { gathering with their own initial } \\
\text { screening of suppliers e.g. the } \\
\text { information gathering process } \\
\text { for social criteria was executed } \\
\text { after the buyers had conducted } \\
\text { the traditional Q,C,D analysis. } \\
\text { Only if the potential supplier } \\
\text { met the economic deliverables, } \\
\text { a social sustainability analysis } \\
\text { would be performed. Slightly } \\
\text { different social criteria is } \\
\text { looked at in the companies. }\end{array}$ & $\begin{array}{l}\text { Intermediaries claim to } \\
\text { heavily support the } \\
\text { information gathering } \\
\text { of supplier behaviour } \\
\text { for buyers to analyse } \\
\text { using their platforms. }\end{array}$ & $\begin{array}{l}\text { Specific types of } \\
\text { sustainability } \\
\text { information need to } \\
\text { be gathered for SRP, } \\
\text { beyond usual Q,C,D } \\
\text { requirements. } \\
\text { There is a reliance } \\
\text { on intermediaries to } \\
\text { support the process. }\end{array}$ \\
\hline 昜 & 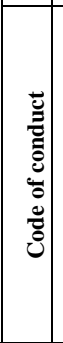 & $\begin{array}{l}\text { The policy } \\
\text { guidelines provided } \\
\text { for suppliers } \\
\text { outlining } \\
\text { expectations of the } \\
\text { purchaser. }\end{array}$ & $\mathbf{x}$ & $\mathbf{x}$ & $\begin{array}{l}\text { "We have policies and } \\
\text { standards suppliers can } \\
\text { use to identify our } \\
\text { expectations. We } \\
\text { expect to see evidence } \\
\text { through corrective } \\
\text { action as we go } \\
\text { through the supplier } \\
\text { selection process" } \\
\text { Global Procurement } \\
\text { Category Manager. }\end{array}$ & $\mathbf{x}$ & $\mathbf{x}$ & $\begin{array}{l}\text { "Codes of } \\
\text { conducts are } \\
\text { useful to set } \\
\text { expectations for } \\
\text { suppliers but for } \\
\text { sustainability, it } \\
\text { goes beyond this } \\
\text { in terms of } \\
\text { evidencing just } \\
\text { compliance" } \\
\text { Sustainability } \\
\text { Analyst. }\end{array}$ & $\mathbf{x}$ & $\mathbf{x}$ & $\begin{array}{l}\text { "We expect } \\
\text { suppliers to operate } \\
\text { in accordance with } \\
\text { [our intermediary's] } \\
\text { ethical trading code } \\
\text { of practice. We will } \\
\text { ensure this before we } \\
\text { embark on a } \\
\text { relationship" } \\
\text { Corporate } \\
\text { Sustainability } \\
\text { Manager. }\end{array}$ & $\begin{array}{l}\text { All cases have publicly available } \\
\text { code of supplier conduct } \\
\text { documents and all refer to them } \\
\text { as expectations that must be met. } \\
\text { None of the case documentation } \\
\text { mentions that suppliers must } \\
\text { engage in corrective action before } \\
\text { exchange, even though it is an } \\
\text { expectation of the buyer. All } \\
\text { codes of conducts are based on } \\
\text { the requirements set by SEDEX. }\end{array}$ & $\begin{array}{l}\text { Code of conducts differ in } \\
\text { length and content. }\end{array}$ & $\begin{array}{l}\text { Intermediaries support } \\
\text { the claim that suppliers } \\
\text { are expected to } \\
\text { demonstrate alignment } \\
\text { to codes of conducts by } \\
\text { actioning risky areas of } \\
\text { their practice flagged } \\
\text { by a CAR, before } \\
\text { selection is agreed. }\end{array}$ & $\begin{array}{l}\text { Just following a } \\
\text { code of conduct is } \\
\text { not sufficient for } \\
\text { SRP. } \\
\text { There is an implicit } \\
\text { requirement for } \\
\text { suppliers to } \\
\text { demonstrate goal } \\
\text { congruence before } \\
\text { selection. }\end{array}$ \\
\hline
\end{tabular}




\begin{tabular}{|c|c|c|c|c|c|c|c|c|c|c|c|c|c|c|c|}
\hline & \multirow{4}{*}{ 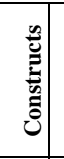 } & \multirow{4}{*}{$\begin{array}{l}\text { Definition } \\
\text { derived from } \\
\text { the data }\end{array}$} & \multicolumn{9}{|c|}{ WITHIN CASE ANALYSIS } & \multicolumn{3}{|c|}{ CROSS CASE ANALYSIS } & \multirow{4}{*}{ Summary } \\
\hline & & & & & CASE 1 & & & CASE 2 & & & CASE 3 & \multirow{3}{*}{ Case similarities } & \multirow{3}{*}{ Case variations } & \multirow{3}{*}{ Validation case support } & \\
\hline & & & & & BevAware & & & ustProduce & & & pparelTrade & & & & \\
\hline & & & $\dot{\Xi}$ & $\ddot{\circ}$ & Example of evidence & $\dot{\Xi}$ & نٌّ & $\begin{array}{l}\text { Example of } \\
\text { evidence }\end{array}$ & $\dot{\Xi}$ & $\stackrel{\leftrightarrow}{\circ}$ & $\begin{array}{l}\text { Example of } \\
\text { evidence }\end{array}$ & & & & \\
\hline & $\begin{array}{l}\overrightarrow{0} \\
\vec{n} \\
\vec{n}\end{array}$ & $\begin{array}{l}\text { Acceptance of } \\
\text { the truth of a } \\
\text { statement } \\
\text { without } \\
\text { evidence or } \\
\text { investigation. }\end{array}$ & $\mathrm{x}$ & $\mathrm{x}$ & $\begin{array}{l}\text { "We rely on trust to } \\
\text { guarantee suitable } \\
\text { behaviour from our } \\
\text { suppliers for joint goal } \\
\text { alignment, especially for } \\
\text { our sustainability targets. } \\
\text { As well as contracts, that } \\
\text { trust reduces our risk [...] } \\
\text { We need trust to ensure } \\
\text { suppliers will and are } \\
\text { following our policy when } \\
\text { they are not being } \\
\text { monitored" Sustainability } \\
\text { and Responsibility } \\
\text { Performance Manager. }\end{array}$ & $\mathrm{x}$ & $\mathrm{x}$ & $\begin{array}{l}\text { "Where we have a } \\
\text { good relationship } \\
\text { with a supplier, } \\
\text { we have more } \\
\text { trust" Category } \\
\text { Group Project } \\
\text { Manager. }\end{array}$ & $\mathrm{x}$ & & $\begin{array}{l}\text { "We trust } \\
\text { suppliers more if } \\
\text { they show us } \\
\text { examples of their } \\
\text { sustainability } \\
\text { behaviour and if } \\
\text { they have previous } \\
\text { corrective action } \\
\text { evidence we trust } \\
\text { them to do } \\
\text { something similar } \\
\text { again" Corporate } \\
\text { Sustainability } \\
\text { Manager. }\end{array}$ & $\begin{array}{l}\text { All cases explain in the } \\
\text { interviews the importance of } \\
\text { trust on improving } \\
\text { sustainability. For } \\
\text { ApparelTrade, trust is less } \\
\text { explicit in the documentation. }\end{array}$ & $\begin{array}{l}\text { BevAware and } \\
\text { JustProduce mention } \\
\text { trust in some of their } \\
\text { documentation but } \\
\text { ApparelTrade (who } \\
\text { have less public } \\
\text { documents) do not } \\
\text { mention it in their } \\
\text { documents. }\end{array}$ & $\begin{array}{l}\text { Intermediaries go some way to } \\
\text { providing the trust between buyers } \\
\text { and suppliers by facilitating the } \\
\text { supplier selection process in terms } \\
\text { of information gathering and } \\
\text { developing CARs. They claim to } \\
\text { support the build up of trust through } \\
\text { this process. }\end{array}$ & $\begin{array}{l}\text { Buyers require } \\
\text { transparency of data, } \\
\text { engagement behaviours } \\
\text { and knowledge } \\
\text { development of } \\
\text { sustainable practices to } \\
\text { ensure trust in the } \\
\text { partnership before the } \\
\text { supplier selection decision } \\
\text { has been formalised. }\end{array}$ \\
\hline 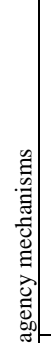 & 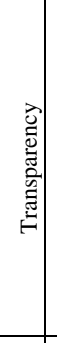 & $\begin{array}{l}\text { Clarity and } \\
\text { openness. }\end{array}$ & $\mathrm{x}$ & $\mathrm{x}$ & $\begin{array}{l}\text { "We need to see evidence } \\
\text { of transparency of } \\
\text { supplier conduct before } \\
\text { we work with them" } \\
\text { Supplier Performance } \\
\text { Manager. }\end{array}$ & $\mathrm{x}$ & $\mathrm{x}$ & $\begin{array}{l}\text { "Some suppliers } \\
\text { are more } \\
\text { forthcoming with } \\
\text { amount and type } \\
\text { of information } \\
\text { than others. We } \\
\text { are more likely to } \\
\text { work with the } \\
\text { more open ones" } \\
\text { Group Head of } \\
\text { Sustainability. } \\
\end{array}$ & $\mathrm{x}$ & $\mathrm{x}$ & $\begin{array}{l}\text { "Our suppliers } \\
\text { should be } \\
\text { committed to } \\
\text { openness and } \\
\text { transparency in } \\
\text { their supply } \\
\text { chains from the } \\
\text { outset. We don't } \\
\text { expect to have to } \\
\text { ask for this" } \\
\text { Ethical Trading } \\
\text { Manager. } \\
\end{array}$ & $\begin{array}{l}\text { Transparency is an expectation } \\
\text { of suppliers and a } \\
\text { demonstrable trait that buyers } \\
\text { feel that suppliers can offer } \\
\text { pre-selection. Information } \\
\text { exchange is the first way a } \\
\text { supplier can evidence } \\
\text { transparency. All three cases } \\
\text { expect CARs to be presented } \\
\text { prior to a transaction. }\end{array}$ & $\begin{array}{l}\text { The number, context } \\
\text { and severity of the } \\
\text { CAR report is different } \\
\text { for all three cases, due } \\
\text { to the variety in nature } \\
\text { of the industry or } \\
\text { organisational risk } \\
\text { preferences. } \\
\text { Threshold levels of } \\
\text { evidence vary for each } \\
\text { case and are context } \\
\text { specific. }\end{array}$ & $\begin{array}{l}\text { Transparency is the service that the } \\
\text { intermediaries are providing so they } \\
\text { support that this is crucial for SRP, } \\
\text { even more so than for regular } \\
\text { buyer-supplier exchanges due to the } \\
\text { nature of social sustainability. } \\
\text { Intermediaries again support the } \\
\text { claim that suppliers are expected to } \\
\text { demonstrate alignment to codes of } \\
\text { conducts by actioning risk areas of } \\
\text { their practice flagged by a CAR } \\
\text { before selection is agreed. }\end{array}$ & $\begin{array}{l}\text { Buyers require CAR } \\
\text { improvements to be } \\
\text { shown by the supplier } \\
\text { prior to embarking on a } \\
\text { transactional exchange. }\end{array}$ \\
\hline 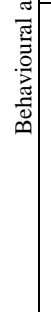 & 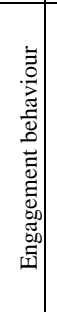 & $\begin{array}{l}\text { The way in } \\
\text { which a person } \\
\text { or organisation } \\
\text { acts or conducts } \\
\text { itself, especially } \\
\text { towards others. }\end{array}$ & $\mathrm{x}$ & $\mathrm{x}$ & $\begin{array}{l}\text { "We see it as an } \\
\text { engagement process with } \\
\text { suppliers. You can't do } \\
\text { everything but you need } \\
\text { to decide where your risk } \\
\text { is" Global Sustainability } \\
\text { Assistant. }\end{array}$ & $\mathrm{x}$ & $\mathrm{x}$ & $\begin{array}{l}\text { "Our best supplier } \\
\text { relationships are } \\
\text { those that we } \\
\text { either work on } \\
\text { sustainability } \\
\text { projects together } \\
\text { with or who } \\
\text { communicate to us } \\
\text { about their own" } \\
\text { Sustainability } \\
\text { Analyst. }\end{array}$ & $\mathrm{x}$ & $\mathrm{x}$ & $\begin{array}{l}\text { "We have direct } \\
\text { influence over } \\
\text { whether we } \\
\text { choose to use a } \\
\text { supplier based on } \\
\text { what we know" } \\
\text { Ethical Trading } \\
\text { Manager. }\end{array}$ & $\begin{array}{l}\text { Supplier engagement is } \\
\text { mentioned in all } 3 \text { case's } \\
\text { documentation. Supplier } \\
\text { engagement prior to a } \\
\text { transactional exchange and } \\
\text { beyond is mentioned in case } \\
\text { interviews. No public } \\
\text { documents disclose the nature } \\
\text { of adopting CARs prior to } \\
\text { exchange. }\end{array}$ & $\begin{array}{l}\text { ApparelTrade are } \\
\text { further along in their } \\
\text { SRP experiences and } \\
\text { achievements and have } \\
\text { more joint } \\
\text { sustainability projects } \\
\text { with suppliers than } \\
\text { BevAware or } \\
\text { JustProduce. }\end{array}$ & $\begin{array}{l}\text { Intermediaries specifically support } \\
\text { the engagement between supplier } \\
\text { and buyer before exchange through } \\
\text { facilitation of CARs. }\end{array}$ & $\begin{array}{l}\text { SRP requires early } \\
\text { involvement supplier } \\
\text { development before } \\
\text { supplier selection has } \\
\text { been formalised. }\end{array}$ \\
\hline & 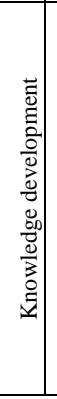 & $\begin{array}{l}\text { Demonstrating } \\
\text { actionable } \\
\text { improvements. }\end{array}$ & $\mathrm{x}$ & $\mathrm{x}$ & $\begin{array}{l}\text { "We need to develop the } \\
\text { knowledge together to } \\
\text { improve the situation. We } \\
\text { expect suppliers to take } \\
\text { some leadership here in } \\
\text { terms of implementing } \\
\text { improvements" } \\
\text { Sustainability and } \\
\text { Responsibility } \\
\text { Performance Manager. }\end{array}$ & $\mathrm{x}$ & $\mathrm{x}$ & $\begin{array}{l}\text { "In food we have } \\
\text { many positive } \\
\text { projects going on } \\
\text { and sustainability } \\
\text { development is on } \\
\text { the up" Category } \\
\text { Group Project } \\
\text { Manager. }\end{array}$ & $\mathrm{x}$ & $\mathrm{X}$ & $\begin{array}{l}\text { "We work with } \\
\text { suppliers who do } \\
\text { something } \\
\text { developmental } \\
\text { with CARs and } \\
\text { show us progress. } \\
\text { We often input } \\
\text { into these } \\
\text { projects" Ethical } \\
\text { Supply Chain } \\
\text { Manager. }\end{array}$ & $\begin{array}{l}\text { All three cases' documentation } \\
\text { mention that improvements } \\
\text { and developments of } \\
\text { sustainability performance are } \\
\text { required. All interviews stated } \\
\text { that supplier knowledge } \\
\text { development must be evident } \\
\text { before a positive supplier } \\
\text { selection decision is made. All } \\
\text { three organisations work with } \\
\text { the suppliers to do this. }\end{array}$ & $\begin{array}{l}\text { BevAware and } \\
\text { JustProduce use } \\
\text { assistance of the } \\
\text { intermediary in CARs } \\
\text { more, prior to } \\
\text { exchange. } \\
\text { ApparelTrade use the } \\
\text { intermediary less and } \\
\text { take more of a direct } \\
\text { approach through } \\
\text { preference, rather than } \\
\text { clear benefits of doing } \\
\text { it this way. }\end{array}$ & $\begin{array}{l}\text { Intermediaries detail how CARs } \\
\text { should be addressed and completed } \\
\text { both in supplier development post } \\
\text { exchange but also before selection } \\
\text { has occurred. They claim it is a } \\
\text { growing expectation of buyers to } \\
\text { demonstrate a good working } \\
\text { relationship. As both buyers and } \\
\text { suppliers sometimes do not have the } \\
\text { knowledge to complete the CAR, } \\
\text { the intermediaries facilitate this and } \\
\text { by doing so, expand the transferable } \\
\text { knowledge and best practice } \\
\text { globally. }\end{array}$ & $\begin{array}{l}\text { Buyers require evidence } \\
\text { of suppliers' knowledge } \\
\text { development capabilities } \\
\text { of social sustainability } \\
\text { practices of suppliers } \\
\text { before formal supplier } \\
\text { selection has taken place } \\
\text { and expect this to continue } \\
\text { afterwards. }\end{array}$ \\
\hline
\end{tabular}

Int. $=$ interviews Table 3. Final construct definitions with supporting quotations and cross case comparisons
Table 


\section{Findings}

The findings from the case studies are grouped into two sections based on the evidence from the eight main constructs derived from the main cases. The reason firms perform SRP are because it is in their sustainability strategy due to reputational risk management. The traditional transactional mechanisms that buyers are utilising to select suppliers are presented as the information gathering process and supplier code of conduct that they must follow. Then the relational behaviours that complement and complete the components needed for SRP are introduced as trust, transparency, engagement and knowledge development. In particular, the knowledge development construct demonstrated by the social sustainability corrective action of the supplier is investigated further to understand its role in suppler selection. All cases displayed a change in process relating to early involvement supplier development at the preselection stage, unusual for food, beverage and apparel sectors. All cases evidenced both traditional agency and behavioural agency activities during the process, placing supplier's sustainability progress as critical to the supplier selection decision.

\subsection{SRP under PAT}

Research into the three purchasing organisations (and ratified by SC intermediary data) showed that a strong transactional process remains key to SRP. While the relational side is gaining importance, an area that is difficult to measure, the process of the transactions is still crucial. This involves a clear sustainability strategy, risk management, information gathering about supplier behaviour and designing and implementing a code of conduct outlining expectations for suppliers.

All cases showed that a sustainability strategy and reputational risk management are the reasons behind the introduction of early supplier development for SRP. The sustainability strategy is explicit so that suppliers are clear about buyer's expectations, although appear in different types of documents e.g. strategy documents for BevAware and JustProduce and in reports for ApparelTrade. All cases confirmed that information gathering and code of conducts are unnegotiable, unchanged parts of the supplier selection process. Putting a code of conduct in place for suppliers was key for all three cases and supported by the two validation cases (as their main function is the gathering of the sustainability information using self-assessment 
tools), to ensure communication of sustainability goals is absolutely clear. The Supplier Engagement Manager at InfOrg explains that:

"The information gathering can be laborious and complex but the main thing for suppliers to realise is that buyers need access to the information whether the social criteria is met or not".

The results are so explicit in the coding that both received high inter-rater reliability scores on their first iteration, showing their embedded and established part of the process. The ApparelTrade Corporate Sustainability Manager explains how the code of conduct protects against risk and sets expectations before the transaction:

"One of the risks mentioned in our annual report is the failure to ensure compliance in the supplier base to ethical trading policy. There is potential for the organisation to suffer negative customer and stakeholder sentiment with associated impact on customer and investor appeal if this happens. We are an active member of [intermediary organisation] and we actively engage with our supply base and expect suppliers to operate in accordance with its ethical trading code of practice. We will ensure this before we embark on a relationship".

Evidence of goal alignment with the code of conduct is required by the buyers, but this being prior to exchange is an implicit expectation and not mentioned in documentation. The findings show that social sustainability requirements supplement and complement Q,C,D and do not replace them e.g. BevAware only consider social sustainability criteria after initial financial screening.

\subsection{SRP under behavioural agency theory (relational mechanisms)}

In order for SRP to occur, the case studies provide evidence that there are four main behaviours that suppliers need to demonstrate to buyers. Demonstrating trust, transparency, engagement and a knowledge development capability are behaviour traits which are crucial. Supplier trust is a factor required by buyers associated with striving for mutually beneficial goals for both parties and linked to non-economic criteria. The validation cases support this construct of going 
beyond compliance and minimal expectations as a way to reduce the number of audits and inspections which not only cost time and money but are often deemed necessary where trust does not exist. The Supplier Engagement Manager at InfOrg explains that

"The assistance we provide in supplier selection for firms with strong sustainability values is focused on building a trusting relationship before they have started working together so that the foundation of the relationship is stronger".

Transparency emerged as a collaborative construct from the case study analysis, linked to the other three behaviours. Transparency can be a demonstration of trust as the sharing of private information prior to exchange is a risk in itself for the supplier. Transparency in the past has traditionally been linked to the reporting and audit mechanisms rather than the perception of the forthcoming supplier who is willing to share objectives and strive for mutual goals which is more apparent in a social sustainability context and is strongly demonstrated through the use of CARs, heavily discussed in the interview data by all cases.

The threshold value was determined through the SRP approach of the buyer working in conjunction with a SC intermediary. The SC intermediary provided information on the criteria that had been pre-selected by the purchaser as being important in terms of their organisational stakeholders, sustainability strategy and code of conduct. The data collected included indirect measures such as child labour, health and safety, working practices and equal opportunities, for which the potential supplier would have to provide, through the intermediary, evidence of sustainability performance. If the supplier met the minimum threshold of the buyer, direct contact would follow to discuss the remaining issues that have been flagged. The information gathering process for social criteria was executed after the buyers had conducted the traditional Q,C,D analysis. Only if the potential supplier met the economic deliverables, a social sustainability analysis would be performed.

CARs identify good practice examples and non-compliances, with action plans and progress updates against them. Once the supplier has provided the evidence, non-compliance issues are decided by the buyer or from advice given from SC intermediaries. Suppliers must comment on the root cause (to ensure continuous compliance in future), preventative and corrective actions, timescales and corrective evidence. Typically CARs will report firstly on labour standards such as freedom of association, collective bargaining, living accommodation, 
children and young workers, wages, working hours, discipline and grievance. Secondly, they cover health and safety standards including training, exposure to hazardous materials, emergency and procedures, and machinery safety. Thirdly environmental standards are included and finally other business ethics such as anticorruption must be reported on. As an example, if the CAR identifies a supplier using excessive overtime, firstly the root cause will be identified as possibly poor production planning, poor training of operatives, or bottlenecks in the operation holding the material flow up. If poor production planning was identified as the root cause, the CAR would need to show actions put in place to improve forecasting to ensure worker conditions improved through less overtime.

Suppliers must complete CARs with evidence of improvements that are already ongoing in the selection phase. The Supplier Engagement Manager at InfOrg explains that part of their service is offering a tool:

"To drive transparency through your supply chain and actually have an efficient way for collecting and analysing data - that's the primary use. And then from there it's up to the company how they use that information" [as different buyers may require different levels of transparency]. Most of our partners use the CARs to augment self-assessment data."

Engagement behaviour is essential for the behavioural agency aspect of SRP as

"While we engage with suppliers throughout our supply chain, our main focus is on working with those with whom we can have the most immediate relationships" (BevAware Supplier Performance Manager).

The engagement factors took some time to define as they needed to represent an action which showed the relationship between the buyer and supplier. These factors are collaboration, commitment, communication and cooperation. Collaboration refers to the degree that the supplier actively engages with the buyer to achieve mutual goals of social sustainability. An example of this is both buyer and supplier joining the ETI and working on joint projects together. Commitment refers to the long term relational aspect of the agreement. It is demonstrated by open communication and evidence of cooperation which might be shown through investing in areas suggested by the knowledge development construct, such as corrective action. Communication refers to the level that the supplier engages with the buyer 
in terms of their sharing of information. It is linked to transparency, but is not the same as transparency. Transparency is the level of disclosure of information offered by the supplier, whereas communication is the open channel of information from supplier to buyer both forthcoming and requested. Thus, cooperation refers to the degree that the supplier is willing to engage with the buyer in terms of requests and expectations pre-selection. One example recorded is:

"We have input into supplier behaviour improvement because we can. We meet with sourcing on a monthly basis, provide them with any concerns or any escalation points about our suppliers, and that actually feeds into their decision of whether to use a supplier" (Ethical Supply Chain Manager, ApparelTrade).

All four of these engagement behaviours are linked to knowledge development as these traits are needed for the supplier to demonstrate use of the CARs to improve their behaviour in certain areas deemed important to the buyer, as ratified by the validation cases who provide these CARs and opportunities. Knowledge development as a reflective, forward moving solution was revealed as imperative, especially as longer term relationships were most appealing and a strategic direction in all cases. This is a clear move from a transaction based approach to more of a collaborative long term partnership, shifting from the transaction as the foundation of the exchange to the relationship and pursuit of mutual goals as the basis for trading.

The knowledge development construct reveals the most interesting change for the transition from traditional purchasing to SRP. In order to excel in sustainability behaviour, improvements must be shown prior to a sale being established. For example, the Global Sustainability Manager in Procurement at BevAware described their strong focus on knowledge development;

"People need to know what to do and how to do it. I fear we focus too much on simply a solution - this isn't about finding a solution, it is about changing the landscape and that might take time because we need to develop a way to do it".

The Business Relationship Manager at SociOrg explains that: 
"We're very much trying to move away from coming in to a supplier, pointing out an area of risk and leaving because they might not even know what that means, let alone know how to identify what the problems are and how to go about fixing them. We like to see ours as an end-to-end programme including handholding them from the start of that journey of making those positive changes."

Suppliers are asked to demonstrate resolution of the CARs from the pre-selection screening before any type of commercial exchange has taken place, showing commitment to both the relationship and ongoing sustainability improvements. Early supplier involvement is not found to occur for the same reasons as in open innovation, where it is more common. For SRP, the benefits of sustainability knowledge development contribute to the buyer's corporate sustainability objectives and risk mitigation, rather than shorter development cycles, lower developing costs and technology alignment.

The three case study organisations were found to be at different stages of SRP evolution however, it was discovered through our cross case analysis that delivering a SRP approach through purchasing involved the same sequence and number of steps. The three purchasers were all established at selecting suppliers after the CAR was developed and actioned. ApparelTrade were transitioning to continue this practice without the use of an intermediary as they were gaining social sustainability knowledge through experience - enough to be able to understand and use criteria without assistance. BevAware and JustProduce felt this was still unmanageable without intermediary assistance supporting the information gathering and CAR development.

The complementary use of transactional and relational factors in selecting suppliers through SRP highlighted the early engagement of knowledge development in the process. Employing a knowledge development process of using CARs that supported both parties in understanding what best practice in social sustainability means, was highlighted as a major step by the case study buyers. Working collaboratively on CARs required the development of knowledge transfer to achieve mutual sustainability goals with suppliers adopting governance responsibilities. Commitment by the supplier to addressing CARs was shown through the engagement with the rigorous buyer requirements. Suppliers disclose information through selfassessment and CARs which carries a risk to their own operations but demonstrates 
transparency. This is effort exerted by the supplier to fulfil the buyers' information needs and demonstrates a willingness to improve processes in advance of any economic exchange. The development in SRP beyond transactional process agency based factors to behavioural agency dimensions was seen in all cases and confirmed by the SC intermediaries.

In summary, the findings suggest that for supplier selection in SRP; buyers are driven by their sustainability strategies and risk associated with poor sustainability practice in their supply chains when selecting suppliers; buyers require evidence of code of conduct compliance and willingness of information sharing to mitigate information asymmetry; buyers require transparency of data, engagement behaviours and knowledge development of sustainable practices to ensure trust in the partnership; and buyers require CAR improvements to be made by the supplier prior to embarking on a transactional exchange. Within the context of SRP, the behavioural agency aspects were evident before supplier selection was finalised, therefore questioning the sequence of events and validity of historical purchasing frameworks as a mechanism for driving SSSCM. Undertaking and engaging with collaborative actions before supplier selection, along with the transactional dimensions were viewed by buyers as critical in moving towards a positive selection decision. This shift in governance from principal-led to agent-led, under behavioural agency theory is a key finding. Suppliers were expected to demonstrate transparency through sharing confidential data on socially sustainable factors that demonstrated goal alignment, to be considered for selection.

\section{Discussion}

Purchasing organisations have historically selected, monitored and controlled suppliers through clearly defined criteria and measures based on Q,C,D (Ellram 1990; Sarkis and Talluri 2002). The sequence of activities in sourcing socially sustainable suppliers would initially appear to resemble the traditional sourcing and supplier management pathway outlined in the extant literature (de Boer, Labro and Morlacchi 2001). But integration of environmental and social issues into the market transaction approach has forced buyers to reconsider their management of the status quo selection process (Luthra et al. 2017). The nature of social dimensions, with their varied and non-standardised aspects, means that firms are finding ways to drive change and improvement in social performance by ensuring suppliers have aligned goals and can demonstrate this before selection has occurred. Suppliers can demonstrate trust 
to the buyer by engaging with the process and demonstrating willingness to meet the purchasers' criteria including partaking in knowledge development and corrective action, as early knowledge development can reduce risk (Chen, Sohal and Prajogo 2016).

Our findings have significant implications for the progression of social sustainability breakthroughs in industries typically plagued by compliance issues. The behavioural agency theory approach, putting the supplier's ability to deliver sustainability goals and shift some governance responsibility from the principal to the agent, is important. There are learnings for buyers pursuing a SRP strategy to ensure improvements on CARs are evident prior to exchange and lessons for suppliers that to remain competitive, this requirement is now necessary for partnering in a socially sustainable supply chain. With the influence and stature that large global purchasing firms have, these developments will have a positive impact on society as social sustainability credentials are improved. Our findings indicate that a threshold value of socially sustainable performance needs to be reached before any exchange can take place. Evaluating the social aspects of suppliers represented an additional step in the historical supplier assessment and evaluation approach. The benefits of supplier development (such as those described by Sancha et al. 2015b) are realised earlier for the buyer, supplier and wider society.

\subsection{SRP Process}

The SRP actions and activities of the buyer, in terms of supporting the supplier to improve processes prior to any agreements, is contrary to the extant literature. Researchers highlight that an established and successful relationship is a prerequisite to embarking on supplier development and knowledge transfer activities (Krause 1999; Krause, Scannell and Calantone 2000; Prahinski and Benton 2004; Talluri and Narasimhan 2004; Araz and Ozkarahan 2007; Modi and Mabert 2007). However, for SRP which requires CARs to be reported against and actions taken before the exchange has occurred, this is contrary to the normal supplier management processes which views supplier development as a post-selection activity (Krause, Handfield and Scannell 1998; Prahinski and Benton 2004; Talluri and Narasimhan 2004; Araz and Ozkarahan 2007; Wagner and Krause 2009). Yawar and Seuring (2015) recognise supplier development as crucial to the management of social issues in supply chains but they did not 
consider it at the pre-selection stage or recognise a change in the process of purchasing or supplier selection.

What differs from traditional purchasing is that supplier development activities are being started before an exchange has occurred. Changes to the way suppliers are selected have occurred because sustainability has serious reputational implications for the buyer. SRP is embarked upon where a sustainability strategy supporting the endeavour is evident. This sustainability strategy is a response to reputational risk for the buyer. The first proposition is:

\section{Proposition 1.}

SRP requires early involvement supplier development before transactional exchange in order to demonstrate goal congruence and reduce reputational risk to the buyer.

\subsection{Post-exchange supplier development activities as pre-selection requirements}

Gold, Trautrims and Trodd (2015) recognised that supplier development could be an effective response to eradicating modern slavery in supply chains and called for new theory development in SCM by focusing on sustainability capability, which the SRP process delivers. Our research found that the supplier must evidence their capabilities by showing demonstrable improvements on the CAR before exchange occurs. Gold, Trautrims and Trodd (2015) propose a conceptual framework incorporating detection (including targeted investigation) and remediation (including supplier development and capacity-building) which our process supports, albeit at the pre-exchange point, not as a typical post-exchange supplier development activity. However, rather than failing to detect exploitative practices, as NGOs accuse buyers of doing (Wolf 2014), the pre-exchange CAR now shows that investigation is conducted in a much earlier phase in SRP (see Figure 3), demonstrating a solution to any accusation of pseudotransparency and exhibiting more commitment to unearthing poor practice in the supply network.

In traditional purchasing, suppliers who have been chosen may then partake in supplier development programmes, but with this knowledge development activity moving to a preselection task, direct activities are now required at the start of the sequence rather than at the end in an established exchange. 


\section{Proposition 2.}

\section{SR purchasers require evidence of knowledge development capabilities of social sustainability practices of suppliers before transactional exchange.}

\subsection{Behavioural agency theory in SRP}

Our research shows that behavioural agency theory provides a better framework for theorising the buyer-supplier exchange in SSSCM as the agent's (supplier's) behaviour of pre-exchange engagement and knowledge development - to demonstrate goal congruence - supplements traditional PAT mechanisms in the supplier selection process. In contrast to the standard agency framework, which focuses on monitoring costs and incentive alignment, behavioural agency theory places suppliers' success at the centre of the agency model, arguing that the interests of buyers and suppliers are most likely to be aligned if suppliers can perform to the best of their abilities (Sancha et al. 2015b). Our research supports that behavioural agency attributes are required to facilitate post-monitoring activity to pre-selection.

Through behavioural agency theory in socially SSCM, moral hazard is reduced because suppliers have to demonstrate actions on agreed upon sustainability performance objectives in advance. Adverse selection is reduced because through the CAR, the supplier shows representation of their ability to meet these requirements. Thus the goal-setting theory embedded within behavioural agency theory plays a part to align buyers and suppliers for SSSCM success. This evidence will go some way towards the process changes solicited by New (2015) for modern slavery eradication. Thus the focus on the process differences between traditional purchasing and SRP are more valuable than simply enhancing codes of conduct. In his paper, New (2015) explains how conventional CSR approaches may not be capable of addressing the problem of forced labour in the chain, as a result of tools giving only an appearance of behaviour improvement. The SRP process preventing transactions before behaviours have changed is thus more beneficial. New (2015) suggests there are issues with power in the chain which need to be addressed but SRP goes some way to contributing to a better landscape for vulnerable workers and with purchasing's position at the beginning of the supply chain activity, may have a more substantial impact than reactive behaviours postexchange where the consequences are likely to be less. 
Therefore, the typical PAT explanation of the buyer and supplier exchange has evolved in SRP. Behavioural agency theory more suitably explains the SRP process.

\section{Proposition 3.}

SRP requires behavioural agency mechanisms in the supplier selection process that complement traditional transactional forms of governance.

To enhance Yawar and Seuring's (2015) development of supplier development strategies to help resolve social issues, we propose the supplier development strategy for SRP is to bring the activity into the pre-exchange realm. The movement of supplier development to the preselection stage, through SRP, has altered the theoretical framework of traditional supplier selection (see Figure 3). Supplier development now commences at pre-selection and continues if the supplier becomes part of the SSSCM of the buyer. If supplier development "forms the core construct particularly for bringing about social improvements to workers in global supply chains" (Yawar and Suering, 2015, 16) then embarking on this knowledge development approach pre-exchange is a positive outcome for SSSCM. This paper has an additional contribution than the design of the SRP process in its use of behavioural agency theory in this context. Johnsen, Miemczyk and Howard (2017) found that there is a significant lack of theory attribution to sustainable purchasing and SC research and that instead, it is common for authors to declare they are using theory but actually they are developing SCM models or literature. This paper explains the development of the SRP supplier selection process using behavioural agency theory which firstly responds to the request to explore other areas than the resource based view (RBV) and stakeholder theory and secondly responds to the criticism of applicable theory rather than models; both observations made by Johnsen, Miemczyk and Howard (2017). 


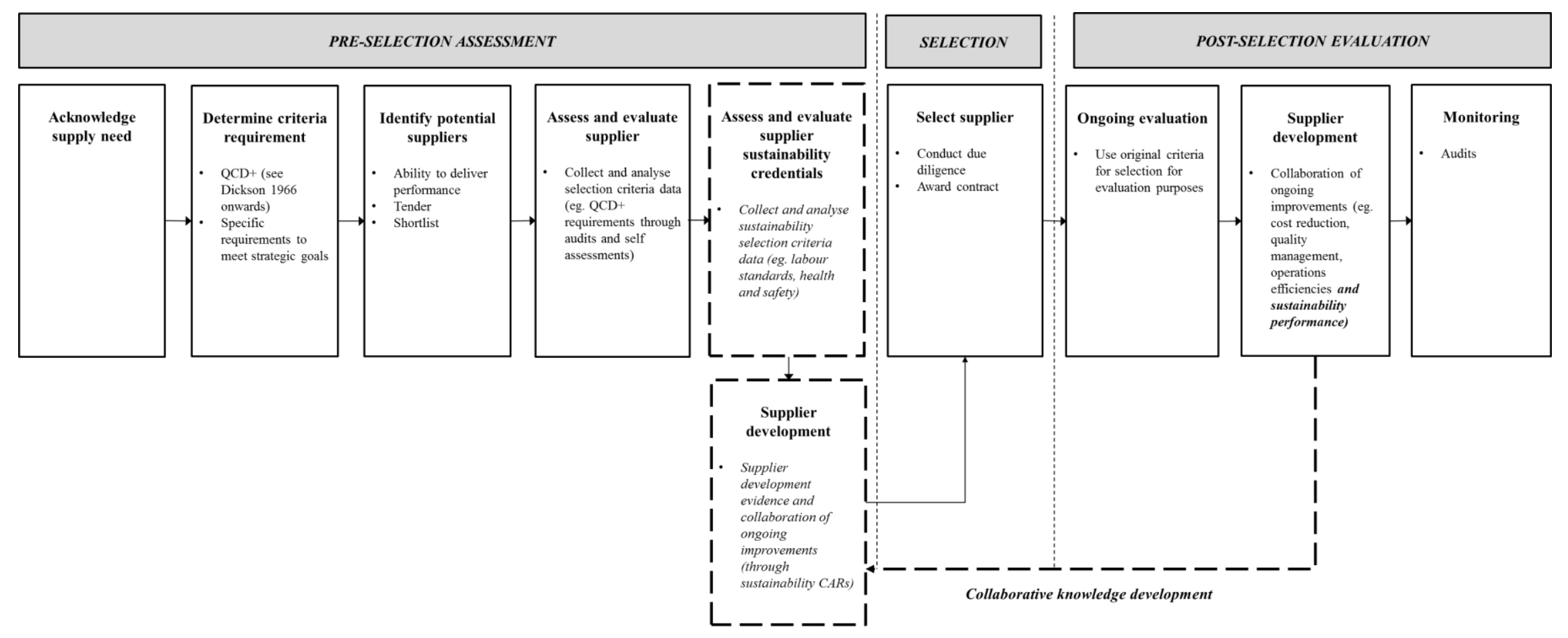

Figure 3. Shift in activity from post-selection evaluation to pre-selection assessment in SRP 


\section{Conclusions}

Our initial research interest was to seek and explain any changes that have occurred in the traditional supplier selection process as organisations move towards the establishment of SSSCM. The research highlighted the need for potential suppliers to meet the Q,C,D performance expectation needs of the buyer before any information is gathered, identified and analysed on their social sustainability. Assessing the social credentials of suppliers was an additional step that was incorporated into the traditional process. The major change to the supplier selection process was a resequencing of the post-selection supplier management process. For example, the identification and explanation of the need for end-to-end supplier management in SRP which incorporates supplier development activities in pre-selection tasks. Our analysis emphasises the earlier engagement of these development activities than previously suggested by literature. We find evidence of a reappraisal of a traditional SC system and governance structure that has changed as a result of the sustainability pursuit, as predicted by Garetti and Taisch (2012).

The research shows the purchaser's requirements of the supplier to demonstrate components of the knowledge development construct (improvement and development) in the pre-selection stage as well as the post-selection evaluation stage, therefore altering the traditional supplier selection process to support SSSCM. Many studies posit that supplier development has benefits to both the buyer and supplier but we suggest that for SRP, supplier development activities should be introduced earlier in the process. For sectors that do not traditionally practice open innovation where early supplier involvement does occur, this is a key finding. Deploying SRP can have implications on the resources and focus of buyers. The traditional specialisation split between supplier selection and development in organisations (Sarkis and Talluri 2002, Park et al. 2010) means that utilising SRP may lead to challenges in terms of skill sets and realignment of purchasing roles.

We also sought to advance an understanding of how traditional PAT has evolved for SRP. Through qualitative research an analysis of the supplier selection functions of focal firms pursuing a social sustainability agenda was provided. The findings presented and discussed advance an understanding of the behavioural agency attributes that complement traditional agency forms of governance from the start of the process. By pursuing mutual goals, aligned through CARs and facilitated by SC intermediaries, behavioural agency theory is being 
employed whereby the success of the supplier will extinguish moral hazard and adverse selection. This shows a development driven by an SRP approach which challenges buyers to deliver the synergetic benefits of managing exchanges through traditional agency and behavioural agency norms (Liu, Luo and Liu 2009) from the revised supplier selection process.

\subsection{Managerial Implications}

The explorative case study approach utilised in this research offers an insight into the purchasers' actions and perspectives on the changing nature of the supplier selection process from its traditional function to its significant role in realising the social sustainability objectives of the firm. Findings from this study have relevance for purchasing professionals who are striving to comprehend the complexity and challenge that establishing and delivering SSSCM entails. The framework that is proposed provides a platform for practitioners to develop and implement their own supplier selection decisions to meet sustainability objectives of the firm. In particular the interplay between PAT and behavioural agency dimensions of selection provide insights into the dynamics of the environment that they operate within. The resource implications of these changes in terms of focus, skills and time need to be considered (Gunasekaran, Nachiappan and Shams 2017) as organisations manage the SRP approach to delivering SSSCM.

\subsection{Research Limitations and Areas for Further Research}

Research limitations of the study exist, and in doing so indicate areas for future research directions. Although the conceptual framework can be generalised to purchasers pursuing a social sustainability agenda, it requires further investigation into the departures from existing assumptions about traditional buyer-supplier relationships. Investigating the supplier view of the exchange is one way to enhance this (Cole, 2017; Kim et al. 2019) and could be considered a limitation of this study, albeit one that has been recognised and addressed through the SC intermediary validation data. 
We cannot profess to be able to apply our findings to a population level but with three major global players researched, all who have changed their supplier selection processes, we have laid the way for future research into this type of investigation. Studies using a larger sample, longitudinal studies, survey data or where SRP behavioural agency aspects are lower or missing could be considered. We do not use a control sample of firms not using SRP, but chose to use the literature on traditional supplier selection processes instead.

Purchasing decisions need to be inclusive of all three TBL dimensions; therefore the proposed SRP framework should be integrated with the other important drivers of sustainability in a specific context to improve its impact for buyers. The supplier selection process developments should be tested with environmental criteria to evidence whether the same demonstrations of collaborative knowledge development are necessary for those partnerships to flourish. The priority and sequencing approaches of types of supplier selection criteria in SRP would provide valuable further insight.

\section{REFERENCES}

Araz, C. and I. Ozkarahan. 2007. "Supplier evaluation and management system for strategic sourcing based on a new multicriteria sorting procedure." International Journal of Production Economics 106 (2): 585-606.

Ashby, A., M. Leat, and M. Hudson-Smith. 2012. "Making connections: a review of supply chain management and sustainability literature." Supply Chain Management: An International Journal 17 (5): 497-516.

Ayuso, S., M. Roca, and R. Colome. 2013. "SMEs as 'Transmitters' of CSR Requirements in the Supply Chain.” Supply Chain Management: An International Journal 18 (5): 497-508

Barratt, M., T.Y Choi, and M. Li, 2011 "Qualitative case studies in operations management: Trends, research outcomes, and future research implications." Journal of Operations Management, 29 (4): 329-342.

Berrone, P. and L.R. Gomez-Mejia. 2009. "Environmental performance and executive compensation: An integrated agency-institutional perspective". Academy of Management Journal 52 (1): 103-126.

Carter, C. R. 2005. "Purchasing social responsibility and firm performance: the key mediating roles of organizational learning and supplier performance." International Journal of Physical Distribution \& Logistics Management 35 (3): 177-194.

Carter, C. R. and M. M. Jennings. 2004. "The role of purchasing in corporate social responsibility: a structural equation analysis." Journal of Business Logistics 25 (1): 145-186.

Carter, C. R. and P. L. Easton. 2011. "Sustainable supply chain management: evolution and future directions." International Journal of Physical Distribution \& Logistics Management 41 (1): 46-62.

Chai, J., J.N. Liu, and E.W. Ngai. 2013. "Application of decision-making techniques in supplier selection: A systematic review of literature". Expert Systems with Applications 40 (10): 3872-3885.

Chen, J., A. S. Sohal, and D. I. Prajogo. 2016. "Supply risk mitigation: a multi-theoretical perspective." Production Planning \& Control 1-11.

Cheraghi, S. H., M. Dadashzadeh, and M. Subramaniam. 2004. "Critical success factors for supplier selection: an update." Journal of Applied Business Research 20 (2): 91-108.

Cole, R. 2017. "Getting their wings: Angel agents live on-Supplier stewards in sustainable enterprise." Journal of Corporate Citizenship, 67: 3-11.

Cuevas-Rodríguez, G., L.R. Gomez-Mejia and R.M. Wiseman. 2012. "Has agency theory run its course?: Making the theory more flexible to inform the management of reward systems". Corporate Governance: An International Review 20 (6): 526-546. 
da Mota Pedrosa, A., D. Näslund and C. Jasmand. 2012. "Logistics case study based research: towards higher quality”. International Journal of Physical Distribution \& Logistics Management, 42 (3): 275-295.

de Boer, L., E. Labro and P. Morlacchi. 2001. “A review of methods supporting supplier selection”, European Journal of Purchasing \& Supply Management 7 (2): 75-89.

Despeisse, M., F. Mbaye, P.D. Ball and A. Levers. 2012. "The emergence of sustainable manufacturing practices". Production Planning \& Control 23 (5): 354-376.

Dickson, G. W. 1966. “An analysis of vendor selection systems and decisions.” Journal of Purchasing 2 (1): 517.

Eisenhardt, K. M. (1989). Agency theory: An assessment and review. Academy of Management Review, 14 (1), 57-74.

Eisenhardt, K. M., and M. E. Graebner. 2007. "Theory building from cases: opportunities and challenges." Academy of Management Journal 50 (1): 25-32.

Eisenhardt, K.M. (1989) 'Building theories from case study research', Academy of Management Review 14(4): 532-550.

Ellram, L.M. 1990. “The supplier selection decision in strategic partnerships.” Journal of Purchasing and Materials Management 26 (4): 8-14.

Fayezi, S., A. O'Loughlin, and A. Zutshi. (2012). "Agency theory and supply chain management: a structured literature review”. Supply Chain Management: An International Journal, 17 (5): 556-570.

Foerstl, K., C. Reuter, E. Hartmann, and C. Blome. 2010. "Managing supplier sustainability risks in a dynamically changing environment - Sustainable supplier management in the chemical industry." Journal of Purchasing \& Supply Management 16 (2): 118-130.

Garetti, M., and M. Taisch. 2012. "Sustainable manufacturing: trends and research challenges". Production Planning \& Control: The Management of Operations 23(2-3): 83-104.

Genovese, A., S.C. Koh, N. Kumar and P. K. Tripathi. 2014. "Exploring the challenges in implementing supplier environmental performance measurement models: a case study." Production Planning \& Control 25 (13): 1198-1211.

Ghijsen, P. W. T., J. Semeijn, and S. Ernstson. 2010. "Supplier satisfaction and commitment: The role of influence strategies and supplier development." Journal of Purchasing and Supply Management 16 (1): 1726.

Gimenez, C., and E. M. Tachizawa. 2012. "Extending sustainability to suppliers: A systematic literature review." Supply Chain Management: An International Journal 17 (5): 531-

Glaser, B. G., and A. L. Strauss. 1967. "The discovery of grounded theory: Strategies for qualitative research." New Jersey: Transaction Publishers.

Gold, S., A. Trautrims and Z. Trodd. 2015. "Modern slavery challenges to supply chain management." Supply Chain Management: An International Journal, 20 (5): 485-494.

Gunasekaran, A., N. Subramanian and S. Rahman. 2017. "Improving supply chain performance through management capabilities." Production Planning \& Control 28 (6-8): 473-477.

Hahn, C. K., C. A. Watts, and K. Y. Kim. 1990. "The supplier development program: A conceptual model." Journal of Purchasing and Materials Management 26 (2): 2-7

Hannibal, C., Kauppi, K., 2018. Third party social sustainability assessment: Is it a multi-tier supply chain solution? International Journal of Production Economics.

Hartmann, J. and S. Moeller. 2014. "Chain liability in multitier supply chains? Responsibility attributions for unsustainable supplier behavior." Journal of Operations Management 32 (5): 281-294.

Johnsen, T. E., J. Miemczyk and M. Howard. 2016. "A systematic literature review of sustainable purchasing and supply research: Theoretical perspectives and opportunities for IMP-based research”. Industrial Marketing Management

Kim, S., S.M. Wagner, and C. Colicchia. 2019. "The impact of supplier sustainability risk on shareholder value." Journal of Supply Chain Management.

Kogg, B. 2003. Power and incentives in environmental supply chain management. Strategy and Organization in Supply Chains, 65-81.

Krause, D.R. 1999. "The antecedents of buying firms' efforts to improve suppliers." Journal of Operations Management 17(2): 205-224.

Krause, D.R., R. B. Handfield, and T. V. Scannell. 1998. "An empirical investigation of supplier development: reactive and strategic processes." Journal of Operations Management 17(1): 39-58.

Krause, D.R., T. V. Scannell, and R. J. Calantone. 2000. "A structural analysis of the effectiveness of buying firms' strategies to improve supplier performance." Decision Sciences 31(1): 33-55.

Krippendorff, K. 2004. "Reliability in content analysis." Human Communication Research 30 (3): 411-433.

Leire, C., and O. Mont. 2010. "The implementation of socially responsible purchasing." Corporate Social Responsibility \& Environmental Management 17 (1): 27-39. 
Li, S., M. Kang and M.H. Haney. 2017. "The effect of supplier development on outsourcing performance: the mediating roles of opportunism and flexibility”. Production Planning \& Control 28 (6-8): 599-609.

Liu, Y., Y. Luo, and T. Liu. 2009. "Governing buyer-supplier relationships through transactional and relational mechanisms: Evidence from China.” Journal of Operations Management 27 (4): 294-309.

Luthra, S., K. Govindan, D. Kannan, S.K. Mangla, and C.P. Garg. 2017. “An integrated framework for sustainable supplier selection and evaluation in supply chains". Journal of Cleaner Production 140 : 16861698.

Luzzini, D., M. Amann, F. Caniato, M Essig, and S. Ronchi. 2015. The path of innovation: purchasing and supplier involvement into new product development. Industrial Marketing Management, 47, 109-120.

Maignan, I., B. Hillebrand, and D. McAlister. 2002. "Managing socially-responsible buying: how to integrate non-economic criteria into the purchasing process.” European Management Journal 20 (6): 641-648.

Marshall, D., L. McCarthy, C. Heavey and P. McGrath, 2015. "Environmental and social supply chain management sustainability practices: construct development and measurement." Production Planning \& Control 26(8): 673-690.

McCutcheon, D., and J. Meredith. 1993. "Conducting case study research in operations management." Journal of Operations Management 11(3): 239-256.

Miemczyk, J., T. E. Johnsen, and M. Macquet. 2012. "Sustainable purchasing and supply management: a structured literature review of definitions and measures at the dyad, chain and network levels." Supply Chain Management: An International Journal 17 (5): 478-496.

Modi, S. B., and V. A. Mabert. 2007. "Supplier development: Improving supplier performance through knowledge transfer." Journal of Operations Management 25 (1): $42-64$.

Nagati, H., and C. Rebolledo. 2013. "Supplier development efforts: The suppliers' point of view." Industrial Marketing Management 42 (2): 180-

New, S.J., 2015. "Modern slavery and the supply chain: the limits of corporate social responsibility?." Supply Chain Management: An International Journal 20(6): 697-707.

Pacheco, D.F. and T.J. Dean. 2015. "Firm responses to social movement pressures: A competitive dynamics perspective." Strategic Management Journal 36(7): 1093-1104.

Pagell, M., Z. Wu. 2017. Business implications of sustainability practices in supply chains. In Sustainable Supply Chains (pp. 339-353). Springer International Publishing.

Pagell, M., and Z. Wu. 2009. "Building a more complete theory of sustainable supply chain management using case studies of 10 exemplars." Journal of Supply Chain Management 45 (2): 37-56.

Park, J., K. Shin, T. W. Chang, and P. Park. 2010. "An integrative framework for supplier relationship management." Industrial Management \& Data Systems 110 (4): 495-515.

Park-Poaps, H., and K. Rees, K. 2010. "Stakeholder forces of socially responsible supply chain management orientation." Journal of Business Ethics 92 (2): 305-322.

Paulraj, A. 2011. "Understanding the relationships between internal resources and capabilities, sustainable supply chain management and organizational sustainability." Journal of Supply Chain Management 47 (1): 19-37.

Pepper, A. 2015. Behavioural agency theory. In The Economic Psychology of Incentives (pp. 26-58). Palgrave Macmillan UK.

Pepper, A. and J. Gore. 2015. "Behavioral agency theory: New foundations for theorizing about executive compensation". Journal of Management 41 (4): 1045-1068.

Poppo, L. and T. Zenger. 2002. "Do formal contracts and relational governance function as substitutes or complements?” Strategic Management Journal 23 (8), 707-725.

Prahinski, C. and W.C. Benton. 2004. "Supplier evaluations: communication strategies to improve supplier performance." Journal of Operations Management 22 (1): 39-62.

Sancha, C., C. Gimenez, V. Sierra and A. Kazeminia. 2015b. "Does implementing social supplier development practices pay off?”. Supply Chain Management: An International Journal 20(4): 389-403.

Sancha, C., A. Longoni and C. Giménez. 2015a. "Sustainable supplier development practices: drivers and enablers in a global context". Journal of Purchasing and Supply Management 21(2): 95-102.

Sanchez Rodrigues, V., D. Stantchev, A. Potter, M. Naim and A. Whiteing. 2008. "Establishing a transport operation focused uncertainty model for the supply chain". International Journal of Physical Distribution \& Logistics Management 38(5): 388-411.

Sarkis, J. and S. Talluri. 2002. “A model for strategic supplier selection,” Journal of Supply Chain Management 38 (1): 18-28.

Sarkis, J., Q. Zhu, and K.H. Lai. 2011. “An organizational theoretic review of green supply chain management literature". International Journal of Production Economics 130 (1): 1-15.

Schneider, L. and C. M. Wallenburg. 2012. "Implementing sustainable sourcing-Does purchasing need to change?” Journal of Purchasing \& Supply Management 18 (4): 243-257. 
Seuring, S. and M. Müller. 2008. "From a literature review to a conceptual framework for sustainable supply chain management." Journal of Cleaner Production 16 (15): 1699-1710.

Seuring, S. and S. Gold. 2013. "Sustainability management beyond corporate boundaries: from stakeholders to performance." Journal of Cleaner Production 56: 1-6.

Srnka, K. J., and S. T. Koeszegi. 2007. "From words to numbers: how to transform qualitative data into meaningful quantitative results.” Schmalenbach Business Review 59 (1): 29-57.

Stevenson, M., and Cole, R. 2018. "Modern slavery in supply chains: a secondary data analysis of detection, remediation and disclosure". Supply Chain Management: An International Journal, 12(3): 81-99.

Talluri, S,. and R. Narasimhan. 2004. "A methodology for strategic sourcing." European Journal of Operational Research 154 (1): 236-250.

Talluri, S., R. Narasimhan, and W. Chung. 2010. "Manufacturer cooperation in supplier development under risk". European Journal of Operational Research 207 (1): 165-173.

Voss, C., N. Tsikriktsis and M. Frohlich. 2002 "Case research in operations management”, International Journal of Operations \& Production Management 22 (2): 195-219.

Wagner, B. and G. Svensson. 2010. "Sustainable supply chain practices: research propositions for the future." International Journal of Logistics Economics \& Globalisation 2 (2): 176-186.

Wagner, S.M. and D. R. Krause. 2009. "Supplier development: communication approaches, activities and goals." International Journal of Production Research 47 (12): 3161-3177.

Wagner, S.M.. 2011. "Supplier development and the relationship life-cycle." International Journal of Production Economics, 129 (2): 277-283.

Walker, H. L., Z. Radnor, D. Chicksand and G. Watson. 2015. "Theoretical perspectives in operations management: an analysis of the literature". International Journal of Operations and Production Management 35 (8): 1182-1206.

Weber, C. A., J. R. Current, and W. C. Benton. 1991. "Vendor selection criteria and methods." European Journal of Operational Research 50 (1): 2-18.

Wilhelm, M. M., C. Blome, V. Bhakoo and A. Paulraj. 2016. "Sustainability in multi-tier supply chains: Understanding the double agency role of the first-tier supplier". Journal of Operations Management 41: 4260.

Wolf, J. 2014. "The relationship between sustainable supply chain management, stakeholder pressure and corporate sustainability performance". Journal of Business Ethics 119(3): 317-328.

Xu, L., Shi, X., Xie, Y., and Tsai, S. B. 2019. Corporate Social Responsibility-Based Supplier Selection Process in Sustainable Supply Chains. In Corporate Social Responsibility: Concepts, Methodologies, Tools, and Applications (pp. 155-172). IGI Global.

Yawar, S. A., and S. Seuring. 2015. "Management of social issues in supply chains: a literature review exploring social issues, actions and performance outcomes." Journal of Business Ethics 1-23.

Yin, R.K. 1984. Case Study Research - Design And Methods. Sage Publications. Beverly Hills

Yu, F., Yang, Y., and Chang, D. 2018. "Carbon footprint based green supplier selection under dynamic environment”. Journal of Cleaner Production 170, 880-889.

Zhang, M., K.S. Pawar and S. Bhardwaj. 2017. "Improving supply chain social responsibility through supplier development". Production Planning \& Control : 1-12.

Zhang, M., K. S. Pawar, J. Shah, and P. Mehta. 2013. "Evaluating outsourcing partners' capability: A case study from the pharmaceutical supply chain.” Journal of Manufacturing Technology Management 24 (8): 10801101

Zorzini, M., L. C. Hendry, F. A. Huq, and M. Stevenson. 2015. "Socially responsible sourcing: reviewing the literature and its use of theory." International Journal of Operations \& Production Management 35 (1): 60109.

Zsidisin, G. A., and L.M. Ellram. 2003. “An agency theory investigation of supply risk management”. Journal of Supply Chain Management 39(2): 15-27.

Zsidisin, G. A., and M.E. Smith. 2005. "Managing supply risk with early supplier involvement: a case study and research propositions". Journal of Supply Chain Management 41(4): 44-57. 


\section{Appendix 1 \\ Interview protocol}

\section{QUESTIONS FOR MAIN CASES}

What is sustainability in the context of purchasing?

What language do you use and why (responsible sourcing/ethical trading etc.)

To what extent is the supplier selection decision made as a result of the process, and as a part of the individual? What is the association to strategic objectives at the supplier selection decision point?

Do you see issues with different people being involved in the overall corporation strategy and those doing the socially responsible purchasing?

How is the socially responsible purchasing process different to the traditional purchasing process?

How are your supplier selection decisions impacted differently to the Q,C,D requirements?

In what ways do your relationships with suppliers come into the final supplier selection decision?

How do you characterise, measure and evolve a socially responsible purchasing supplier selection success?

To what extent do you work with competitors to get a sector wide approach to what is important in the criteria? 
Appendix 2

Inter-rater reliability for BevAware

\begin{tabular}{l|c|c|c}
\hline \multirow{2}{*}{ Construct } & \multicolumn{3}{c}{ Kappa Agreement } \\
& Document analysis & Interview analysis & TOTAL MEAN \\
\hline Sustainability strategy & 0.803 & 0.793 & 0.798 \\
\hline Risk management & 0.779 & 0.753 & 0.766 \\
\hline Information gathering process & 0.916 & 0.722 & 0.819 \\
\hline Code of conduct & 0.871 & 0.801 & 0.836 \\
\hline Trust & 0.923 & 0.643 & 0.783 \\
\hline Transparency & 0.744 & 0.733 & 0.739 \\
\hline Engagement behaviour & 0.754 & 0.704 & 0.729 \\
\hline Knowledge development & 0.854 & 0.733 & 0.794 \\
\hline
\end{tabular}

